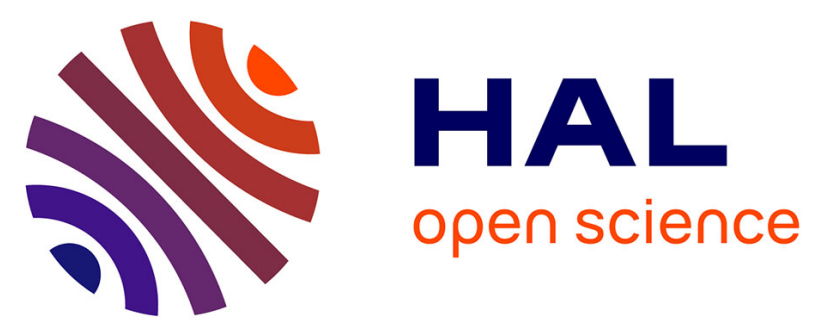

\title{
Grassland-cropland rotation cycles in crop-livestock farming systems regulate priming effect potential in soils through modulation of microbial communities, composition of soil organic matter and abiotic soil properties
}

Marco Panettieri, Julien Guigue, Nicolas Chemidlin Prévost-Bouré, Mathieu Thévenot, Jean Lévêque, Cédric Le Guillou, Pierre-Alain Maron, Anne-Lise Santoni, Lionel Ranjard, Stéphane Mounier, et al.

\section{To cite this version:}

Marco Panettieri, Julien Guigue, Nicolas Chemidlin Prévost-Bouré, Mathieu Thévenot, Jean Lévêque, et al.. Grassland-cropland rotation cycles in crop-livestock farming systems regulate priming effect potential in soils through modulation of microbial communities, composition of soil organic matter and abiotic soil properties. Agriculture, Ecosystems and Environment, 2020, 299, pp.106973. 10.1016/j.agee.2020.106973 . hal-03014052

HAL Id: hal-03014052

https://institut-agro-dijon.hal.science/hal-03014052

Submitted on 9 Mar 2021

HAL is a multi-disciplinary open access archive for the deposit and dissemination of scientific research documents, whether they are published or not. The documents may come from teaching and research institutions in France or abroad, or from public or private research centers.
L'archive ouverte pluridisciplinaire HAL, est destinée au dépôt et à la diffusion de documents scientifiques de niveau recherche, publiés ou non, émanant des établissements d'enseignement et de recherche français ou étrangers, des laboratoires publics ou privés. 
1 Grassland-cropland rotation cycles in crop-livestock farming systems regulate priming effect

2 potential in soils through modulation of microbial communities, composition of soil organic

3 matter and abiotic soil properties.

4 Marco PANETTIERI I ${ }^{\mathrm{a}, \mathrm{b}}$, Julien GUIGUE ${ }^{\mathrm{a}, \mathrm{c}}$, Nicolas CHEMIDLIN PREVOST-BOURÉ ${ }^{\mathrm{d}}$, Mathieu

5 THÉVENOT $^{\mathrm{a}}$, Jean LÉVÊQUE ${ }^{\mathrm{a}}$, Cédric LE GUILLOU ${ }^{\mathrm{d}}$, Pierre-Alain MARON ${ }^{\mathrm{d}}$, Anne-Lise

6 SANTONI $^{\mathrm{a}}$, Lionel RANJARD ${ }^{\mathrm{d}}$, Stéphane MOUNIER ${ }^{\mathrm{e}}$, Safya MENASSERI ${ }^{\mathrm{f}}$, Valérie VIAUD ${ }^{\mathrm{f}}$,

7 Olivier MATHIEU ${ }^{\mathrm{a}}$

8

${ }^{a}$ Biogéosciences, UMR 6282 CNRS, Université Bourgogne Franche-Comté, 6 Boulevard Gabriel, 21000 Dijon, France.

${ }^{\mathrm{b}}$ Present address: Museo Nacional de Ciencias Naturales (MNCN-CSIC), c/Serrano 115-B, 28006 Madrid, Spain

${ }^{c}$ Present address: Chair of Soil Science, Research Department Ecology and Ecosystem Management, Technical University of Munich, 2 Emil-Ramann-Straße, 85354 Freising, Germany

${ }^{d}$ INRA, UMR 1347 Agroécologie, F-21065 Dijon, France

${ }^{e}$ Université de Toulon, AMU, CNRS, IRD, MIO Toulon, CS 60583, 83041 Toulon Cedex 9

${ }^{f}$ INRA, UMR 1069 SAS, F-35042 Rennes, France

Corresponding author: Marco PANETTIERI ; ORCID : $\underline{\text { https://orcid.org/0000-0003-4769-8955 }}$

email : marco.panettieri.soil@gmail.com; marco.panettieri@ csic.es Telephone +34665125289

Keywords: Soil Carbon; Water-Extractable Organic Carbon; Grassland; Cropland; Variance 


\section{Abstract}

Soils can act as a carbon sink, and the chemical and biological transformation of vegetal litter into soil organic matter (SOM) is widely influenced by land-use and other biogeochemical parameters. However, the increase of new carbon inputs to soil has the potential to trigger the mineralization of stabilized SOM, a process called priming effect.

The objective of this manuscript is to investigate, at a landscape scale $\left(5 \mathrm{~km}^{2}\right)$, the factors influencing the susceptibility of SOM to priming effect. To achieve this objective, physical, chemical, and metagenomics analyses were conducted on 88 soil samples and successively combined with agronomical data and soil incubation for the quantification of carbon fluxes.

Variance partitioning models highlighted that priming effect is controlled by complex interactions of biotic and abiotic factors, which include soil chemistry, quality of SOM, shape and abundance of microbial communities. Fluorescence properties of the dissolved organic matter has been found as a strong descriptor for priming effect. Depending on the time of crop rotation devoted to grassland, two different components leading to priming effect were identified. The introduction of grassland for 40$60 \%$ of the time of rotation achieved the lowest susceptibility to priming effect, and higher indexes of microbial diversity, whereas higher or lower proportions of time of the rotation devoted to grassland resulted in an increase of priming effect and a decrease of bacterial evenness.

\section{Introduction}

A sustainable land management aims to guarantee adequate productivity in agriculture and, at the same time, to provide several ecosystem services (Haines-Young and Potschin, 2010). Among marketed ecosystem services, the production of food, fiber and biofuel are the most acknowledged ones, but there are other non-marketed ecosystem services dealing with water and climate regulation, as well as cultural and aesthetic services (Swinton et al., 2007). Powlson et al. (2011) described soil fertility and the accumulation of soil organic matter (SOM) among the most important services provided by sustainable agricultural practices. There is a scientific consensus about the benefits provided by higher SOM contents, and a major concern regarding the decline of SOM stocks (Kirschbaum, 1995; Minasny et al., 2017; Six et al., 1998; Tiessen et al., 1994). 
The contents of organic matter $(\mathrm{OM})$ in a soil result from the differences between carbon (C) inputs, mainly as aboveground and belowground plant biomass or amendments, and outputs via SOM decomposition by microorganisms, runoff and leaching of particulate and dissolved organic C. The actual stock of $\mathrm{OM}$ in a soil is thus regulated by transformation processes resulting to its stabilization, or its mineralization. The microbial degradation of SOM is a function of its physical accessibility and chemical composition (Kuzyakov and Blagodatskaya, 2015). The addition of exogenous organic matter has been reported to alter SOM decomposition, either by boosting (Chen et al., 2014; Fontaine et al., 2003) or impeding it (Guenet et al., 2010) due to the so-called priming effect (PE) (Bingeman et al., 1953; Kuzyakov et al., 2000).

A considerable effort is necessary to elucidate SOM dynamics and fluxes, especially PE, since they are influenced by a plethora of biotic (interactions with plants, bacteria, fungi, micro fauna) (Tardy et al., 2015) and abiotic factors (content and type of minerals, water balance, atmospheric conditions) (Dignac et al., 2017), acting from micro- to macro-scales (Kuzyakov and Blagodatskaya, 2015). The fluxes of $\mathrm{C}$ in soil may differ strongly from one land-use to another, mediated by shifts in the distribution of microbial communities and functionality, different types and amounts of $\mathrm{C}$ returned to soil, and various plant/soil interactions (Baumann et al., 2013; Dignac et al., 2017; Frank et al., 2002; Tardy et al., 2015). Land-use can change SOM contents drastically, especially in the case of soils devoted to intense anthropic activities (reclamation for urban or agricultural purposes) (Lal and Stewart, 1990). The inclusion of grassland in crop rotation has been highlighted as a way to maintain or improve soil quality in agroecosystems (Glover et al., 2010; Lemaire et al., 2015) and to increase soil C stocks (Smith, 2014; Solomon et al., 2007) because of the modification of both SOM accrual and degradation dynamics (Panettieri et al., 2017). A considerable fraction of C fluxes resulting from the priming effect is assumed to be driven by processes taking place in the rhizosphere (de Graaff et al., 2014; Fontaine et al., 2003), and more extended and dense root networks are generally observed in grassland soils (Jackson et al., 1996; Panettieri et al., 2017). Therefore, the effects of grassland derived $\mathrm{C}$ inputs on PE needs attention in order to estimate the potential effect of the introduction of grasslands into crop rotations on agroecosystems $\mathrm{C}$ balance. 
Kuzyakov et al. (2000) described the mechanisms behind the increased C mineralization responsible of the "real priming effect", triggered by the addition of labile $\mathrm{C}$ sources and/or C-rich rhizodeposition, among other factors. Recent studies have been focused on the PE produced by mining of nitrogen and preferential substrate use (Chen et al., 2014), energy starvation, microbial competition and co-metabolisms (Louis et al., 2016; Tardy et al., 2015), or regulation by redox transformation of soil minerals (Finley et al., 2018; Keiluweit et al., 2015). However, the quantification of the PE mechanism is still limited by methodological uncertainties and by both spatial and temporal variability in its occurrence (Bastida et al., 2019). Moreover, there are concerns about the accuracy of prediction models for global C stocks in which the trigger of SOM mineralization provided by PE is not taken into account (Guenet et al., 2018).

Considering these scientific challenges, the present study has been designed to evaluate the effects of land-use on PE at a landscape scale. Recent studies have been focused on the global assessment of PE predictors (Bastida et al., 2019), but few studies have been targeted at the landscape scale (Craig et al., 2015; Helgason et al., 2014; Walz et al., 2017) and none of them included cropped soils. Unveiling the magnitude and the dynamics of PE in agricultural landscapes is mandatory to calibrate land-use policies. The objective of the project was to identify the factors controlling PE, having a comprehensive approach by integrating soil physical and chemical properties, indexes of soil microbial communities, and agronomic practices in a $5-\mathrm{km}^{2}$ agricultural area in the region of Brittany (France). The site is characterized by high density of pig farming and by the co-existence of mixed annual crops and grasslands (pastures or hayfields, being permanent or included in the rotations). We hypothesized that (i) PE at the landscape scale is related to the community composition of soil microorganisms interacting with the amount and type of OM, and that (ii) land-use management has a significant impact on C fluxes associated with PE.

To test these hypotheses, soil samples were analyzed using a multidisciplinary approach in which soil physical, chemical, and biological variables were tested as descriptors of PE fluxes measured in incubation condition with addition of ${ }^{13} \mathrm{C}$-labeled wheat litter. 


\section{Materials and methods}

\subsection{Study area and soil sampling}

Soil samples were collected from a $5 \mathrm{~km}^{2}$ agricultural area, in the Brittany region (Kervidy-Naizin catchment, N 47.99; W 2.84, France) in June 2013. About $85 \%$ of the surface of the sampling area is devoted to agriculture. The crops covering the larger surfaces are maize and grassland (covering $30 \%$ of the agricultural surface each), followed by other cereals (25\%) and vegetables (10\%). The catchment is an Observatory for Research on the Environment related to agricultural watersheds (SOERE-RBV Critical Zones, www6.inra.fre/ore_agrhys). The climate is oceanic, with a yearly average temperature of $11^{\circ} \mathrm{C}(1994-2013)$ and mean yearly rainfall of $830 \mathrm{~mm}$. The elevation ranges between 98 and $140 \mathrm{~m}$ with mild slopes oriented towards the Naizin river network. Coordinates of the sampling points were distributed using a systematic triangular grid to integrate the maximum of the spatial heterogeneity of the area.

Most soils are well-drained Cambisol (upslope), and some poorly drained Haplic Albeluvisols are located in the foot-slope farms (IUSS Working Group WRB, 2015). Parent material consists of schist and alluvial deposits. The soil texture, measured by standardized 5-fraction granulometry (NF X 31107, AFNOR, 2003), is silty-loam and relatively uniform among the whole area.

Surface composite soil samples were collected at a $0-15 \mathrm{~cm}$ depth with a $5 \mathrm{~cm}$ wide auger. The composite soil samples were made by mixing individual soil cores into one homogeneous sample, sieved in the field $(\varnothing<5 \mathrm{~mm})$, stored at $4^{\circ} \mathrm{C}$ during the transportation to the lab, and split into two subsamples. The first subsample was air-dried and stored at $4^{\circ} \mathrm{C}$ for incubation and chemical analyses. The other subsample was freeze-dried and stored at $-20^{\circ} \mathrm{C}$ until molecular biology analyses were performed. Soil drainage classes and Beven's topographic wetness indexes (Beven and Kirby, 1979) were derived respectively from a detailed soil map (Walter and Curmi, 1998) and from a 20-m digital elevation model. In the framework of the project, farmers were surveyed regarding farming practices, crop rotations, number of cropped species, the quantity of mean annual $\mathrm{C}$ input by crop and grassland residues, $\mathrm{C}$ input by animal manure as well as the quantity of mineral fertilizers applied each year, on an 11-year period (Viaud et al., 2018). 
In this study, 100 independent samples were collected from different farms and divided in five different land-use classes considering the frequency of grassland, expressed as percentage of the rotation time devoted to grassland, as the classification parameter. Main cropped species other than grassland were Maize (silage or grain) in monoculture, or in rotation with cereals (winter wheat, winter barley and triticale), rapeseed, and vegetables. Regarding the descriptors of crop rotation, the number of cropped species, considering grassland a unique specie, was the other variable added to the variance partitioning model, further variables were adding too much complexity to the study and thus discarded. The lower and upper limits of the land-use classification were permanently cropped soils (PC $\mathrm{n}=42$ ), and permanent grassland soils ( $\mathrm{PG} \mathrm{n}=7$ ), respectively. Three land-uses were selected using the different frequency of grassland adopted by farmers on the 11-year period before soil sampling: low-frequency (LO, from 10 to $30 \%$ of time dedicated to grassland, n=13), mid-frequency (MI, 40$60 \%$ of time under grassland, $n=13$ ), and high-frequency (HI, 70-90\% of time under grassland, $n=13$ ). All the grassland farms were mown regularly to feed animals.

After this classification, 88 independent samples respected the criteria of classification, 12 samples collected in wetland, wasteland land and orchards were not considered because of their low representativeness of the area.

\subsection{Soil physical and chemical analyses}

Each measure of soil physical and chemical parameters is a calculated mean of three replicates. The mean weight diameter (MWD) of the air-dried soil aggregates was calculated using the aggregate fractionation method ISO/FDIS 10930 (AFNOR, 2012) derived from the "slow re-wetting" and soil wet sieving procedure described by Le Bissonnais (1996). Bulk density was calculated on a 0-15 cm surface soil layer, using an 8-cm diameter manual soil core sampler. Samples were weighed and dried at $105^{\circ} \mathrm{C}$ for $48 \mathrm{~h}$ to determine gravimetric water content and bulk density.

The total organic $\mathrm{C}$ and $\mathrm{N}$ contents (TOC and TN) and $\mathrm{C}$ isotopic signatures $\left(\delta^{13} \mathrm{C}\right)$ of the soil samples were measured by dry combustion (NF ISO 10694 AFNOR, 1998, and NF ISO 13878, AFNOR 1995)) on an elemental analyzer linked to an isotopic-ratio mass spectrometer (EA-IRMS, VarioMicro 
Cube linked to an Isoprime, Elementar). The stable carbon isotope ratios, ${ }^{13} \mathrm{C} /{ }^{12} \mathrm{C}$ expressed as $\delta{ }^{13} \mathrm{C}$, are calculated against Vienna Pee Dee Belemnite (VPDB) standard.

Moreover, soils were analyzed for the concentrations of oxalate-extractable Si, Fe, Al (NF ISO 22036, (AFNOR 2009), Cu (NF X 31- 120 on EDTA extracted samples (AFNOR 2003b), extractable Olsen's P (NF ISO 11263, (AFNOR 1995b) and pH in a 1:5 water suspension (NF ISO 10390, (AFNOR 2005)).

Pressurized hot-water-extractable organic carbon (WEOC) was obtained using a solvent extractor (ASE200, Dionex Corporation, Sunnyvale, USA) on $5 \mathrm{~g}$ of soil, according to the method of Guigue et al. (2014). The $\mathrm{C}$ concentration in the extracts was measured in a first aliquot by thermal oxidation and NDIR detection (TOC 5000A, Shimadzu), after the addition of $2 \mathrm{M} \mathrm{HCl} \mathrm{(10 \mu l} \mathrm{per} \mathrm{ml} \mathrm{of} \mathrm{sample)} \mathrm{to}$ remove inorganic $\mathrm{C}$. The results of WEOC content were expressed as WEOC contribution to TOC content of soils. The UV-light absorbance of the extracts at $254 \mathrm{~nm}\left(\mathrm{UV}_{254}\right)$ was measured with a Jenway 6715 spectrophotometer and the specific ultraviolet absorbance (SUVA in $1 \mathrm{mg} \mathrm{C}^{-1} \mathrm{~cm}^{-1}$ ) was calculated as an indicator of their content in aromatic moieties (Chin et al., 1994; Weishaar et al., 2003). Another aliquot of the sample was used to measure the $\mathrm{pH}$, then freeze-dried and used for the determination of $\delta^{13} \mathrm{C}$ of WEOC by EA-IRMS.

\subsection{Excitation-emission matrices of fluorescence and PARAFAC modeling}

For fluorescence measurements, triplicates of water-extracted samples $(n=3 \times 88)$ were analyzed using the same settings as in Guigue et al. (2014), with excitation wavelengths ranging from 220 to $500 \mathrm{~nm}$, and emission wavelengths from 250 to $600 \mathrm{~nm}$. The whole dataset corresponding to 264 data matrices (excitation wavelength $\times$ emission wavelength $\times$ fluorescence intensity) was processed for PARAFAC modeling using drEEM toolbox 0.2.0 (Murphy et al., 2014) with Matlab R2016a under Linux. The inner-filter effect was corrected using absorbance spectra during the preprocessing steps. Rayleigh and Raman scatter peaks were excised and substituted with interpolated data using the smootheem function of the drEEM toolbox. The fluorescence signal measured at excitation wavelengths shorter than 250 $\mathrm{nm}$ was noisy, exerting disproportionate leverage on the model, and were thus cut for all EEMs. Each EEM was normalized to its total signal, so that the effect of sample intensity was removed before the 
modeling phase (Murphy et al., 2013). The normalization was reversed after the modeling so that the output values presented correspond to the concentration in the original sample. Outliers identified by their high leverages $(n=11)$ were removed before fitting the final model. A 3-component model explaining $99.7 \%$ of the dataset, having a CORCONDIA of $43.4 \%$ and which was successfully splitvalidated was retained as the final model. The component contribution to each sample fluorescence signal were exported as Fmax in Raman Unit (RU), and then normalized to the DOC concentration in the measured aliquot so that the reported Fmax value is expressed in $\mathrm{RU}$ per $\mathrm{C}$ unit and serves as an indicator of the composition of OM in the samples. The three components of fluorescence identified by the PARAFAC model, named $\mathrm{CP} 1_{\text {(fluo), }}, \mathrm{CP} 2_{\text {(fluo) }}$ and $\mathrm{CP} 3_{\text {(fluo), }}$, comprised two excitation spectral peaks and a single emission peak (Fig. 1). The OpenFluor online database (https://openfluor.lablicate.com) was consulted to match the spectral properties of obtained components with previously identified fluorophores (Murphy et al., 2014).

\subsection{Soil microbial communities}

A characterization of communities of soil microorganisms was carried out after the pre-incubation and just before incubation, following the method proposed by Tardy et al. (2015). For each soil sample, the biomass was derived from the total quantity of crude DNA extracted from $1 \mathrm{~g}$ of lyophilized soil using the ISO 10063 method (Dequiedt et al., 2011; Plassart et al., 2012). Prior to PCR amplification, DNA was purified using a MinElute gel extraction kit (Qiagem Courtaboeuf, France) at INRA Genosol Platform (Dijon, France). Bacterial and fungal diversity were resolved by 454 pyrosequencing, targeting respectively the $16 \mathrm{~S}$ rRNAV3-V4 gene fragment (about 400 bases) and an 18S rRNA gene fragment of about 350 bases. The primer sets were respectively: F479 (5'CAGCMGCYGCNGTAANAC-3')/R888 (5'-CCGYCAATTCMTTTRAGT-3') (Terrat et al., 2012); and FR1 (5'-AICCATTCAATCGGTAIT-3')/FF390 (5'-CGATAACGAACGAGACCT-3') (Plassart et al., 2012). A second PCR was run on purified products from first PCR, adding 10 based-pair multiplex identifiers (MID) at $5^{\prime}$ position to the primers for subsequent sample identification. Final purification and pyrosequencing were carried out on a GS Roche 454 sequencing system. 
Bioinformatics analyses were carried out using the GnS-Pipe of the Genosol Platform (Terrat et al., 2012). Raw reads of $16 \mathrm{~S}$ and $18 \mathrm{~S}$ were sorted according to MID sequences, then filtered on their length, number of ambiguities, and primer sequences. A homogenization procedure by random selection close to the lowest dataset $(2,886$ and 3,286 high-quality sequences for $16 \mathrm{~S}$ and $18 \mathrm{~S}$ rRNA genes, respectively) was carried out to avoid biased comparison of the communities. The dereplicated reads were aligned using infernal alignment and clustered at a 95\% similarity threshold into operational taxonomic units (OTU) by grouping rare reads to abundant ones and not counting differences in homopolymer lengths (Terrat et al., 2012). Single Singletons constituted by unclustered reads detected only once were filtered based on the quality of their taxonomic assignment. Bacterial (16S) and fungal (18S) OTUs were organized into contingency tables reporting the number of reads for each OTU in each sample. In this study, bacterial and fungal richness were expressed as number of OTUs, whereas Pielou's diversity index J' assessed the evenness of the species (Pielou, 1966).

\subsection{Carbon mineralization and priming effect measurements}

The mineralization of SOM was measured during an 80-day incubation experiment. For each sample, six hermetically sealed $150-\mathrm{ml}$ plasma flasks were filled with $30 \mathrm{~g}$ of dry soil and then brought to $60 \%$ of water holding capacity (WHC). To avoid the overestimation of C mineralized in the first days due to the disturbance by soil manipulation and rewetting and to allow soils to reach a more stable state, microcosms were pre-incubated for three weeks at $20^{\circ} \mathrm{C}$ before starting the monitored phase of the incubation.

${ }^{13} \mathrm{C}$-labeled wheat residues $\left(7\right.$ atom $\%{ }^{13} \mathrm{C}$ ) originated from mature wheat plants (harvested 110 days after sowing) cultivated under controlled conditions (Groupe de Recherches Appliquées en Phytotechnologie, CEA Cadarache, France). More precisely, seeds of wheat (Triticum aestivum cv Caphorn) were germinated at $4^{\circ} \mathrm{C}$ in darkness. Plantlets were grown in a mix of sand (1/4) and perlite (3/4) in an air-tight chamber which allowed accurate regulation of atmospheric gas composition and environmental parameters. The plants were watered with half-diluted Hoagland's nutrient solution and $\mathrm{CO}_{2}$ concentration was maintained at $380 \mu \mathrm{Il}^{-1}$. The partial pressures of both ${ }^{13} \mathrm{CO}_{2}$ and ${ }^{12} \mathrm{CO}_{2}$ in the 
242

chamber were continuously monitored by Near Infrared Spectroscopy to determine ${ }^{13} \mathrm{C}$ enrichment of the $\mathrm{CO}_{2}$. Regulation was achieved by automatic injection of pure $\left(>99 \%\right.$ atom\% $\left.{ }^{13} \mathrm{C}\right){ }^{13} \mathrm{CO}_{2}$ (CortecNet, Paris, France).

The microcosms were either amended with ${ }^{13} \mathrm{C}$-residues of wheat (5 $\mathrm{mg} \mathrm{g}^{-1}$ of dry weight soil), which had been finely ground in a bead beater to obtain a powder (wheat residues $\mathrm{C}_{\text {org }}=42.1 \%, \mathrm{C}: \mathrm{N}$ ratio $=$ 77.7 , and ${ }^{13} \mathrm{C}$ labelling $=7.01 \%$ ), or were not amended (control). Wheat residues were used as "model" C-input to assess the response of microbial activity to addition of a given quality of plant material in all soils. Although they were not amended with wheat, control microcosms were mechanically disturbed as amended microcosms. The 528 microcosms $(88$ samples $\times 2$ treatments $\left({ }^{13} \mathrm{C}\right.$-amended and control $) \times 3$ replicates $)$ were incubated in the dark for 105 days under controlled temperature $\left(20^{\circ} \mathrm{C}\right)$ and moisture $(60 \%$ WHC) conditions.

The volume of $\mathrm{CO}_{2}$ produced, used as an index of soil respiration, was sampled after 3, 7, 14, 21, 28, 42, 63, and 80 days. Microcosms were aerated by flushing with air at each sampling date to avoid the perturbation of microbial activity mediated by increased $\mathrm{CO}_{2}$ concentration. Therefore, the measured soil respiration corresponded to the $\mathrm{CO}_{2}$ accumulated in the microcosm headspace between two sampling dates.

At each sampling date, the gaseous phase was sampled in $10 \mathrm{ml}$ airtight flasks, to measure the $\mathrm{CO}_{2}$ concentrations using an Agilent 7890B GC equipped with a thermal conductivity detector coupled to an automatic sampler (Agilent HS7697A Headspace), and in $12 \mathrm{ml}$ airtight flasks, to measure the ${ }^{13} \mathrm{C}$ $\mathrm{CO}_{2}$ enrichment on a Trace Gas analyzer (Micromass) linked to an isotopic-ratio mass spectrometer (Isoprime, Elementar). In this study, only the cumulative values of respired $\mathrm{CO}_{2}$ at the end of the incubation are reported.

The multi-point calibration for $\mathrm{CO}_{2}$ concentrations and ${ }^{13} \mathrm{CO}_{2}$ were both carried out using a GasMix diluter, AlyTech. For the isotopic ${ }^{13} \mathrm{CO}_{2}$ measurements, a variable ${ }^{13} \mathrm{C}$ enrichment, ranging from natural abundance (1.08\%) to $90 \%$ of ${ }^{13} \mathrm{C}$ was used. The accuracy of the calibration, expressed as the difference in ${ }^{13} \mathrm{C}$ percentage between the theoretical and the measured values was less than $0.3 \%$ $\left(\mathrm{R}^{2}=0.99\right)$. 
The use of ${ }^{13} \mathrm{C}$-labeled wheat litter allowed to discriminate the contribution to total respiration $\left(\mathrm{R}_{\mathrm{T}}\right.$ expressed in $\mu \mathrm{g} \mathrm{C}-\mathrm{CO}_{2} \mathrm{~g}^{-1}$ soil) of the SOM- and litter-derived respiration $\left(\mathrm{R}_{\mathrm{S}}\right.$ and $\mathrm{R}_{\mathrm{L}}$, respectively) using mass-balance equations:

Eq. (1)

$$
\left[R_{T}\right]=\left[R_{S}\right]+\left[R_{L}\right] \quad \text { and } \quad\left[R_{T}\right] \times \delta_{T}=\left[R_{S}\right] \times \delta_{S}+\left[R_{L}\right] \times \delta_{L}
$$

Eq. (2)

$$
\left[R_{S}\right]=\frac{\left[R_{T}\right] \times\left(\delta_{T}-\delta_{L}\right)}{\delta_{S^{-}}-\delta_{L}}
$$

Where $\delta_{\mathrm{i}}, \mathrm{i}\{\mathrm{T}, \mathrm{S}, \mathrm{L}\}$ is the ${ }^{13} \mathrm{C}$ signature of the total, SOM- and litter-derived respired $\mathrm{CO}_{2}$, respectively. For the calculation, we made the assumption that the isotopic fractionation between the solid fraction (soil or litter) and the $\mathrm{CO}_{2}$ produced by its mineralization was negligible. Based on these equations, the priming effect was calculated as following:

Eq. (3)

$$
\left[R_{\text {priming effect }}\right]=\left[R_{\text {T amended }}\right]-\left[R_{\text {T control }}\right]-\left[R_{L}\right]
$$

and expressed as mg of $\mathrm{C}-\mathrm{CO}_{2}$ primed per $\mathrm{g}$ of dry weight soil (PE-DW) and per TOC unit (PE/TOC). For this study, values of PE are expressed as cumulative values of $\mathrm{CO}_{2}$ emitted during the incubation.

\subsection{Data analyses}

The analyses were performed with R (R Core Team, http://www.r-project.org/) using "vegan”, "car”, and "leaps" packages (Fox and Weisberg, 2011; Lumley, 2017; Oksanen et al., 2018). Correlation heatmap was generated using "corrplot" package (Wei and Simko, 2017). A variance partitioning approach was used to identify the most significant explanatory variables for the PE, following the method proposed by Chemidlin Prévost-Bouré et al. (2014). Using the Spearman's correlation matrix, variables with a coefficient $\rho \geq 0.8$ were selected and only one of each pair has been included into the models, to avoid collinearity. As a second step, a model selection was conducted by simultaneously minimizing the Bayesian Information Criterion (BIC) and maximizing the adjusted $\mathrm{R}^{2}$ using the function regsubset ("leaps" package). On this subset of explanatory variables, a forward selection procedure was applied to identify the model with the highest $\mathrm{R}^{2}$. The amounts of variance for PE explained by each descriptor, intended as marginal and shared variance, were determined by canonical variation partitioning, whereas the adjusted $\mathrm{R}^{2}$ was determined by redundancy analysis. The variance 
inflation factors (VIF) for each descriptor were calculated using the vif function ("car" package). The descriptors with a $\mathrm{VIF} \leq 3$ were selected for the regression model, limiting the effect of collinearity on the estimated regression coefficients (Sheather, 2009). A total of 1000 permutations of the reduced model were computed to assess the significance of marginal effects.

Using the same procedure described above, two different models were built to further decorticate the

300 collinearity of our data, since an increase of TOC is often correlated to an increase in microbial

301 biomass, WEOC, and thus respiration rates. The first model (identified as "PE-DW") was run using

302 PE and explanatory variables expressed on unit per gram of dry weight soil; the second model was run

using PE and some explanatory variables (WEOC, microbial biomass, and respiration rates) normalized to TOC and identified as "PE/TOC".

To simplify the discussion of the manuscript, only the parameters selected as significant descriptors by the two models were graphically represented and discussed within the text. Boxplots were generated using "ggplot2" (Wickham, 2009) packages in R. Data normality was checked before pairwise comparisons among land-use classes with a Shapiro-Wilk's test. The significant differences for the analyzed parameters between land-use classes were assessed by non-parametric Kruskal-Wallis tests and the Dunn's multiple pairwise comparisons. This step allows to interpret how land-use affects PE descriptors and thus the susceptibility of agroecosystems to PE. Due to the non-normal distribution of most of the values, two different levels of significance were used, $p=0.05$ was evidenced by lowercase letters, while uppercase letters were used when significance satisfied the Bonferroni's correction for 10 hypotheses (significance level $p=0.005$ ). No letters were used in case of the lack of significance

\section{Results}

\subsection{Soil physical and chemical parameters}

The correlation heatmap in figure 2 highlights a strong and diffuse correlation network between the investigated variables.

321 The contents of TOC were significantly higher only for permanent grassland soils, whereas no 322 significant differences were found between the other land-uses (Fig. 3A). TOC and TN were highly 
correlated $\left(\rho^{2}=0.926, p\right.$-value $<0.0001$, Fig. 2) leading to the absence of significant differences among land-uses for $\mathrm{C} / \mathrm{N}$ ratios (10.1 to 10.2 for all treatments, Table S1). Hereafter, the variables TN and TOC/TN will be omitted from the discussion, using TOC contents as the unique reference parameter.

More WEOC was extracted from samples with higher frequency of grassland, the amount of extracted $\mathrm{C}$ normalized to TOC content showed significant differences between cropland and permanent grassland samples only, with larger amounts extracted from the latest (Fig. 3B).

The stability of soil aggregates increased with grassland frequency and the MWD was generally higher for permanent grassland, as well as for HI compared to cropland (Fig. 3D). Texture of analyzed soils evidenced how samples classified as permanent and high-frequency grassland were shifted through a slightly higher presence of clay, compensated by a relative decrease in silt content (Fig. 3E). Concomitantly, permanent grassland samples showed lower and more dispersed $\mathrm{pH}$ values compared to other treatments, even if no significant differences were detected (Fig. 3F). Olsen's P content was higher for cropland than for $\mathrm{HI}$ and permanent grassland (Fig. 3G).

The quantity of crop litter returned yearly to soil differed according to land-use. HI samples received significantly higher inputs of crop litter than MI, even if data dispersion was high (Fig. 3H).

3.2. Qualitative indicators of soil OM obtained from EEM fluorescence and PARAFAC decomposition of water-extractable $\mathrm{OM}$

The components identified from the EEM fluorescence and PARAFAC decomposition are shown in figure 1. The $\mathrm{CP} 1_{\text {(Fluo }}$ most intense peak corresponds to fluorophores defined as "terrestrial humiclike" material and negatively correlated with DOM bioavailability (Lambert et al., 2017; Romero et al., 2017), whereas the $\mathrm{CP} 1_{\text {(Fluo) }}$ secondary peak is similar to fluorophores correlated to biological activity in freshwater DOM (CP3 and CP5 in Lambert et al., 2017). The spectra obtained for CP2 $2_{\text {(Fluo) }}$ resemble those of $\mathrm{CP} 1_{\text {(Fluo) }}$ with a shift towards longer wavelengths, previously described as "terrestrial humic-like" compounds (Stedmon and Markager, 2005) with greater aromaticity, higher molecular weight, and a larger degree of conjugation. Thus, $\mathrm{CP} 2_{\text {(Fluo) }}$ is interpreted as a pool of organic compounds that have undergone more processing and transformation within the soil than $\mathrm{CP} 1_{\text {(Fluo). }}$ 
351 These characteristics and the strong correlations among $\mathrm{CP} 1_{\text {(Fluo) }}$ and $\mathrm{CP} 2_{\text {(Fluo) }}\left(\mathrm{r}^{2}=0.953 ; \mathrm{n}=253\right)$

352 suggest their common sources, probably related to lignin breakdown during plant litter decomposition

353 (Cory and McKnight, 2005).

354 The emission spectra of $\mathrm{CP} 3_{\text {(Fluo) }}$ presented a secondary peak with a "terrestrial humic-like" profile 355 similar to the main peaks of the other two components. The primary peak is, however, found at longer wavelengths for excitation, similar to peaks found for biologically processed organic substrate (Coble, 1996; Søndergaard et al., 2003). Such spectrum is less common in the literature and suggests an even higher degree of aromaticity with extensive and conjugated chemical complexes and low $\delta^{13} \mathrm{C}$ signatures, indicating a scarce contribution of molecules from microbial origin (Dainard et al., 2015; Osburn et al., 2012; Yamashita et al., 2011). Bernard-Jannin et al. (2018) showed that such component is present in soil pore water of a peatland and tends to concentrate during dry period and Lambert et al. (2017) demonstrated its contribution to total fluorescence in rivers during high-water period. Therefore, these fluorescent compounds assigned to $\mathrm{CP} 3_{\text {(Fluo) }}$ likely correspond to highly processed organic material that tends to be preserved in soils, such as biodegraded tannins (Maie et al. 2007), or degradation products inherited from plant litter and swine manure (Hunt and Ohno, 2007; Wheeler et al., 2017). Fluorescence signal of CP3 (Fluo) decreased with higher frequencies of grassland $(\mathrm{p}<0.05$, Fig. 3C), whereas the other fluorophores showed no significant differences among treatment.

\subsection{Carbon fluxes, measured PE and soil microbial communities}

Soil respiration of control microcosms, considered as the potential basal respiration of soil and expressed as mg of $\mathrm{CO}_{2}$ emitted per gram of TOC, increased with grassland frequency, leading to significantly higher values for permanent grassland when compared with cropland (Fig. 4A). On the contrary, for the respiration of amended microcosms, permanent grassland shows significantly lower $\mathrm{CO}_{2}$ emissions compared to $\mathrm{HI}$, LO, and cropland (Fig. 4B). Calculated values of PE-DW were significantly higher $(p<0.05)$ for $\mathrm{HI}$ than for $\mathrm{MI}$ and cropland, and permanent grassland presented huge data dispersion (Fig. 4C). The amount of wheat litter mineralized ranged between the 29.5 and the $42.9 \%$ of the total $\operatorname{litter-}{ }^{13} \mathrm{C}$ added (Table 1), no significant differences between treatments were highlighted. PE was responsible of the mineralization of a portion of TOC ranging between 1.7 and 
$3.2 \mathrm{mg} \mathrm{g}^{-1}$ TOC (Fig. 4D) during the incubation experiment; as a comparison term, basal respiration of soils mineralized between 6.3 and $10.4 \mathrm{mg} \mathrm{g}^{-1}$ of TOC (Fig. 4B). At a $p<0.05$ significance level, soils under LO and HI showed the highest values of PE, permanent grassland the lowest ones.

The influence of legume plants in some temporary and permanent grassland was tested by splitting grassland-only samples into two groups (with and without legumes). Soils from farms with legume crops showed slightly higher PE potential ( $2.40 \pm 0.70$ vs. $2.60 \pm 0.95 \mathrm{mg} \mathrm{g}^{-1}$ TOC) than those without legumes, but with high data dispersion $(\mathrm{p}=0.363)$. Running the same test excluding the samples from permanent grassland reduced the data dispersion, but differences between the two groups were still not significant $(\mathrm{p}=0.187)$.

The quantities of DNA extracted per $\mathrm{g}$ of TOC showed and increasing trend with frequency of grassland, but only HI had significantly higher values $(p<0.05)$ when compared with Cropland (Fig. 4E). LO and MI showed significantly higher values $(p<0.05)$ of bacterial Pielou's indexes of evenness (Eve_B) than permanent grassland (Fig. 4F).

3.4. Variance partitioning models rank variables related to the priming effect potentials

The complete statistical description of analyzed parameters is presented in table 1. Priming effect per unit of dry weight soil (PE-DW) and priming effect per TOC unit (PE/TOC) were selected as dependent variables to build two separate models, and the variance explained by each one of the independent variables was calculated with the variance partitioning models (Fig. 5). The PE-DW and PE/TOC models explained 53.62 and $49.04 \%$ of the total variance, respectively, but a part of it consisted of interactions, i.e. co-variance that cannot be assigned unequivocally to one descriptor. This is a common issue when several independent variables present a co-linearity pattern. For the PE-DW model, the variance assigned to interactions was negative (-6.33\%). This value is due to the use of adjusted $\mathrm{R}^{2}$ values as fitting parameters by the function ordiR2step, combined with a low sample to variable ratio. The negative interactions would lead to a lower percentage of total variance explained, but the value is small enough not to invalidate our analysis, and it may be approximated to zero (Tabachnick and Fidell, 2007). As for positive value of interactions, this percentage of variance cannot be subtracted to the descriptors selected. Among the selected descriptors for this model, frequency of 
grassland was selected as a numeric variable, describing $5.24 \%(p<0.001)$ of the variance and with a positive relationship with measured PE.

The significant variables explaining the PE-DW variations corresponded to water-soluble organic matter chemical composition $\left(\mathrm{CP} 3_{(\mathrm{Fluo})}\right)$, $\mathrm{P}$ availability, microbial biomass, soil $\mathrm{pH}$ and land-use characteristics (grasslands frequency and crop residues). The WEOC amount and clay content were also significant but explained much smaller part of variance. All the variables had a positive effect on the PE-DW with the exception of soil microbial biomass and crop residues.

In the case of PE/TOC model, despite the high contribution of interactions (16.52\%), a large part of PE variance (53.62\%) was explained by a set of only four significant variables with the following hierarchy: MWD, grassland frequency (selected as land-use categories, not numeric), Biomass/TOC and bacterial evenness. Among the different explanatory variables, soil microbial biomass promoted PE/TOC, whereas higher aggregation and bacterial evenness impeded it. The effect of the frequency of grassland on PE/TOC was land-use dependent, indeed PE/TOC was higher at low and high frequency of grasslands in comparison to cropland and lower for samples under mid and permanent grassland.

\section{Discussion}

\subsection{Priming effect in a mosaic of land-uses}

The average $\mathrm{CO}_{2}$ production attributed to $\mathrm{PE}$ for cropped soils ranged between 2 and $3 \mathrm{mg} \mathrm{g}^{-1} \mathrm{TOC}$, a value equal to half of the basal respiration of soils for some treatments. Soil is the source for $60-90 \%$ of the total $\mathrm{CO}_{2}$ fluxes of an ecosystem (Longdoz et al., 2000), and Guenet et al. (2018) showed how prediction on $\mathrm{C}$ sequestration may be halved if $\mathrm{PE}$ is integrated into global $\mathrm{C}$ models. Yet, the mechanisms impacting the $\mathrm{C}$ balance of PE are still under debate, since they may co-occur at the same time, vary from site to site, and be land-use dependent (Chen et al., 2014; Kuzyakov et al., 2000; Razanamalala et al., 2018). In fact, the frequency of grassland in the rotation was selected as a significant descriptor of PE by both variance partitioning models, implying that susceptibility of agroecosystems to PE is partially related to the adopted land-use.

Introduction of grassland into crop rotations results in changes in type and quantity of litter returned to the soil, and potentially supports the establishment of more diverse roots-soil interactions modifying 
soil physical properties and promote the stabilization of roots-derived $\mathrm{C}$ (Cambardella and Elliot, 1992; Panettieri et al., 2017). Most of the soils from permanent grassland received no manuring, aboveground litter was mowed and we could not estimate the quantitative information about rhizodeposition.

The PE-DW model selected the frequency of grassland as a positive descriptor. In the same time, we found positive correlation of TOC and WEOC amounts, as well as clay content with the frequency of grassland. Considering these results together, we hypothesized that the higher TOC contents accumulated under permanent grassland support larger $\mathrm{C}$ mineralization fluxes and strongly influence the PE differences between our land-use classes, as highlighted by the model. This observation justifies our approach consisting of running a second model after normalization of PE fluxes to TOC contents in the soil samples.

For PE/TOC model, the increase of PE was land-use dependent: a positive relationship was found for LO and HI, whereas the effect of MI and permanent grassland were negative. These results add key information to the results for PE-DW model, suggesting that, in our system, PE is triggered by specific frequencies in the occurrence of grassland within crop rotation cycles.

These observations suggest that alternation of cropland and grassland can create favorable conditions for PE. We observed that short-term conversion of agricultural fields into grassland (LO), or shortterm cultivation of prairies (HI), both resulted in increased values of PE/TOC. The similarity between these two situations is that the ecosystem functioning under the dominant land-use is destabilized by the land-use conversion during one to three years per ten years. The mechanisms triggering the PE, however, are likely to differ between the two situations.

If for LO we can hypothesize that frequent tillage and a C-limited environment may change the composition of microbial communities and create biogeochemical conditions prone to PE. The conversion to grassland is likely resulting in changes of SOM composition with more belowground biomass inputs (Jackson et al., 1996) compared to cropland, as well as preservation of organic compounds entering soils through root exudation or root litter (Panettieri et al., 2017). We think that these pools of OM may present a different decomposition stage, and be more easily mineralized by microorganisms than SOM under cropland causing the increased PE under LO land-use (Shahbaz et 
al., 2018). The low $\mathrm{C}$ contents and high $\mathrm{N}$ and $\mathrm{P}$ availability are both favorable conditions for $\mathrm{PE}$ in these soils (Kuzyakov, 2010).

For HI samples, soils are principally devoted to grassland, with higher SOM levels and root inputs. The occasional ploughing of these soils dominated by grassland use is altering soil structure, as shown by lower MWD of aggregates and could promote PE compared to permanent grassland. Indeed, the microbial decomposers in these soils are more likely adapted to the decomposition of SOM made available by the loss of physical protection after ploughing (Kuzyakov, 2010). However, a further characterization of the agricultural practices is necessary to understand this result.

Interestingly, we did not find any increase in PE/TOC for MI land-use class compared to soil under permanent cropland or grassland land-uses. While the processes underlying the different responses of soils under various frequencies of temporary grassland use are hard to demonstrate, MI samples supports the idea that the frequency of switches between land-uses alter soil susceptibility to PE in a non-linear way. Increase or decrease with respect to MI frequency resulted in higher PE values. It is noteworthy that MI soils showed more evenly distributed microbial communities. This result has been related to a greater adaptation and resilience potential of the soil subjected to "intermediate perturbation” (Acosta-Martínez et al., 2008; Shange et al., 2012; Tardy et al., 2015).

\subsection{Influence of land-use on the descriptors of PE-DW model}

The amount of crop litter returned to soil was selected by PE-DW model, showing that a soil with lower input of labile $\mathrm{C}$ represents an energy-limited environment prone to $\mathrm{PE}$ when labile $\mathrm{C}$ is occasionally added (Hamer and Marschner, 2005; Razanamalala et al., 2018). Among the microbiological variables measured, only the quantity of microbial biomass was selected as a predictor of PE-DW, with a negative relation. Higher content of biomass is normally found in soils of "high quality" and microbial interactions are more devoted to mineralization of fresh substrates rather than degradation of physically or chemically protected SOM (Blagodatskaya and Kuzyakov, 2008).

Soil $\mathrm{pH}$ was selected as a positive descriptor of PE-DW, indicating that among the studied soils, those with slightly higher $\mathrm{pH}$ were more prone to $\mathrm{PE}$. In general, soils with slightly higher $\mathrm{pH}$ have higher biomass, higher respiration rates, and faster degradation of SOM. In a single soil type with a similar 
$\mathrm{pH}$ gradient of our study, Aciego Pietri and Brookes (2009) found that $\mathrm{pH}$ and substrate availability affected the structure of microbial community during the decomposition of wheat straw via the succession of litter degradation activities assigned to specific microbial groups. For their study, the increase in soil respiration after straw addition was positively correlated with $\mathrm{pH}$. Taking into account our results, we can therefore assume that a part of the respiration measured by Aciego Pietri and Brookes (2009) at higher $\mathrm{pH}$ was originated by priming effect. No differences in mean $\mathrm{pH}$ were found between land-use classes (Fig. 3F), suggesting that the $\mathrm{pH}$ effect on $\mathrm{PE}$ is independent from our classification.

Further interesting results are the positive relations of WEOC, CP3 ${ }_{\text {(fluo) }}$ and clay with PE-DW. For this study, WEOC per TOC unit increased with frequency of grassland, and is a common early indicator of changes in SOM chemical and biochemical composition (Bongiorno et al., 2019; Panettieri et al., 2014) that increases with the amount of microbial biomass and root exudation (Kalbitz et al., 2000). On one hand, microbial biomass is larger for $\mathrm{HI}$ compared to cropland ( $p<0.05$, Fig. $4 \mathrm{C})$, and a trend towards higher values of WEOC at higher frequencies of grassland was detected. On the other hand, grassland has higher root density than the cereal crops of the study area, especially for surface soils (Jackson et al., 1996), resulting in larger inputs by rhizodeposition and higher microbial activity (van Eekeren et al., 2008).

The component of WEOC fluorescence $\mathrm{CP} 3_{\text {(fluo) }}$ is the variable explaining the largest part of variance in the PE/DW model. It corresponds to a highly processed form of SOM with a high degree of aromaticity, therefore not an ideal source of C for microbes (Coble, 1996; Søndergaard et al., 2003). The relative contribution of $\mathrm{CP} 3_{\text {(fluo) }}$ decreased with the increase of grassland frequency, indicating differences in WEOC composition between land-uses. This result may be explained by larger inputs of fresh and labile organic matter, larger microbial biomass content, and different composition of microbial communities under grassland, while cropland soils generally receive larger quantities of exogenous OM, especially swine manure in the study area. Hunt and Ohno (2007) identified CP3 (Fluo) as being conserved during biodegradation of swine manure. It should be taken into account that the measured $\mathrm{CP} 3_{\text {(fluo) }}$ represents a group of fluorescent compounds referenced as resistant to microbial degradation and co-varying with PE-DW. Each fluorophore identified in WEOC and dissolved organic 
matter is likely accompanied with a consortium of non-fluorescent soluble organic compounds (Stubbins et al., 2014). Deciphering the high molecular complexity of WEOC, e.g. using highresolution mass spectrometry (Guigue et al., 2016; Roth et al., 2014), could allow to investigate organic molecules (e.g. easily degradable ones, N-rich molecules, or organic acids) directly or indirectly related to PE fluxes. The positive relation of $\mathrm{CP} 3_{\text {(fluo) }}$ with PE-DW may be due to: (i) the dynamics of co-metabolism of the compounds forming the consortium with $\mathrm{CP} 3_{\text {(fluo) }}$ in presence of fresh litter (Chen et al., 2014), or (ii) to the temporary stabilization of the consortium with $\mathrm{CP} 3_{\text {(fluo) }}$ via adsorption on clay surfaces and short-range order minerals investigated in recent works (Finley et al., 2018; Keiluweit et al., 2015), most probably a combination of both. This adsorption of highly aromatic compounds can be reversed by input of organic acids from root exudates, manure (Hamer and Marschner, 2005), or produced during the degradation of new litter inputs (Blagodatskaya and Kuzyakov, 2008).

The texture of some of the permanent grassland and, to a minor extent, HI samples shifted through a more clayey texture (Fig. 3E). Since a lower water drainage is often associated with higher clay contents, rotations with higher frequency of grassland may have been established in higher wetness areas, to avoid crop losses due to flooding. The positive effect of clay content on PE could be attributed to an increase of carbon content in these soils.

Olsen P explained the second highest percentage of variance of PE-DW model. High frequencies of grassland were characterized by lower amounts of organic amendment per year and lower available $\mathrm{P}$ contents. In the study area, differences in soil available $\mathrm{P}$ contents are attributable mostly to the spreading of swine manure derived from the widely developed husbandry farms in the area of study (Matos-Moreira et al. 2017). However, the absence of correlation between Olsen P and PE-DW $\left(\rho^{2}=\right.$ 0.035, p-value 0.7) highlight that the variance explained may be due to intragroup variability and/or by different $\mathrm{P}$ speciation, not investigated in this study. The fact that $\mathrm{P}$ is mainly derived from swine manure and that $\mathrm{CP} 3$, the descriptor explaining the higher percentage of variance, was also found in a swine manure degradation experiment (Hunt and Ohno, 2007) points towards the importance of manure degradation in PE dynamics, even if further experiments are needed to corroborate these findings. 
4.3. Influence of land-use on the descriptors of PE/TOC model

548

549

550

551

552

553

554

555

556

557

558

559

560

561

562

563

564

565

566

567

568

569

570

571

572

573

The selected descriptors for PE/TOC model were MWD, microbial C normalized to TOC and bacterial evenness. MWD, a proxy of aggregation, represents a physical protection of SOM from degradation. Thus, the negative relation with PE is easily understandable by the limited access to the protected SOM (Six et al. 1999). The MWD of the water-stable aggregates increased with frequency of grassland, thus lower PE is expected at higher frequencies of grassland. Consistent with literature, temporary and permanent grassland are reported to provide a better protection of aggregates due to two main factors: (i) a lower number of tillage operations which physically disrupt soil aggregates (Six et al. 1999; Panettieri et al. 2015) and (ii) a higher contribution of aggregation factors, such as root exudates and extracellular polymeric substances (Redmile-Gordon et al. 2014) proceeding from a more extended and dense root network (Tisdall and Oades 1982; Jackson et al. 1996; Six et al. 1998; Panettieri et al. 2017). However, the higher PE/TOC measured for HI (Fig. 4D) contrasts this interpretation, suggesting that PE regulation is dependent of other co-occurring factors.

The other two descriptors are related with microbial communities. A higher value of microbial biomass per TOC unit represents the paradigm of a higher microbial growth with higher respiration, but also a more energy limited environment, in which more microorganisms compete for the SOM substrate. The PE/TOC model selected this descriptor as a trigger for PE, and the bacterial evenness as a descriptor with a negative relationship with PE. In a substrate limited environment, competition and predation may increase, inducing a shift of microbial communities through a less even distribution of species (Banerjee et al., 2016; Fontaine et al., 2003). This reduce the resilience of the communities and the capacity of degradation of SOM, limiting the colonization of specific niches and, consequently, making the soil more prone to PE when fresh energy sources are added during incubation (Chen et al., 2014; Razanamalala et al., 2018. Bacterial evenness had a positive correlation with two descriptors of SOM quality (CP3 $3_{\text {(fluo) }}$ and TOC/TN ratio). SOM with a more complex and diverse chemical structure promote the development of a higher bacterial evenness and increase the capacity of microbial communities to degrade substrates (Goldfarb et al., 2011), resulting in a more efficient cycling of the whole pool of allochthonous fresh-C molecules, rather than triggering PE from autochthonous pools of 
SOM. The trend to higher microbial biomass per TOC unit at higher frequency of grassland (Fig. 4C)

575 is consistent with literature for soils under grassland (Baumann et al., 2013; Potthoff et al., 2005),

576

577

578

579

580

581

582

583

584

585

586

587

588

589

590

591

592

593

594

595

596

597

598

599

600

601

since a higher microbial activity is found in rhizosphere and grasslands have a denser and interconnected root architectures, especially for upper soil layers (Jackson et al., 1996; Panettieri et al., 2017; Rasse et al., 2005; Sparling, 1992).

Regarding the composition of soil microbial communities, Le Guillou et al. (2018) conducted a study on the same area using the theory of intermediate perturbation, or hump-backed curve (AcostaMartínez et al., 2008; Shange et al., 2012; Tardy et al., 2015) to relate their metagenomics results with land-use classes. Maximum bacterial diversity occurs at an optimum of soil perturbation, in which more diverse species can proliferate. Considering the classification adopted for the present study, higher values for bacterial richness (Table S1) and evenness (Fig 4E), found for LO and MI confirming that slight modifications in crop rotation led to slightly but significant modification of bacterial richness and evenness. This explanation is in line with the fact that MI soils, corresponding to the ecosystems with the most equal distribution between time under cropland and under grassland, tend to have a higher evenness J' index and a lower potential for PE than LO and HI. It suggests that this frequency of disturbances (tillage and changes in land-use) stimulate the adaptation of microbial communities that become more resilient and are thus able to sustain ecosystem functions better than in agroecosystems where lower frequencies of disturbances had a more negative impact regarding SOM decomposition and PE, i.e. in LO and HI.

\section{Conclusions}

Unveiling the dynamics of priming effect (PE) at landscape scale and on soil samples from real farms is an extremely complex operation, especially for such study area $\left(5 \mathrm{~km}^{2}\right)$ with little heterogeneities in climate, soil types and agricultural management. Chemical and physical interactions with soil mineral phases are fundamental parts of the environmental context in which living organisms are developing. PE represents an indicator of SOM turnover and nutrient cycling, but particular attention must be paid to high values of PE per TOC unit (PE/TOC), a clear indication that C losses may occur. Targeted land-uses may help to mitigate PE/TOC or at least reduce the susceptibility of soils to PE/TOC. For 
the studied area, SOM contents with lower PE potentials are attained for temporary grassland at an optimum of $40-60 \%$ of time devoted to grassland, corresponding to the intermediate frequency in grassland use (MI), while a change in the frequency of grassland seems to create conditions favorable to over-mineralization of soil $\mathrm{C}$ through $\mathrm{PE}$. The MI frequency also represents a microbiological optimum with higher values of bacterial richness and evenness. Higher frequencies of grassland (HI) may tend to increase SOM contents, whereas lower frequency may be uninfluential for this purpose, when compared with permanent cropland. However, HI samples were also intensively prone to PE, and the newly stored SOM may be unstable in the long-term. Interestingly, a pool of specific water soluble organic compounds identified by fluorescence analyses was selected among the descriptors for the susceptibility of soils to PE, highlighting that the composition of soil organic matter in both solid and dissolved phases are potential indicators of PE dynamics, thus offering new possibilities for future research aiming to refine prediction models of $\mathrm{C}$ cycle.

\section{Acknowledgments}

This study has been funded by the French National Research Agency (ANR) through the project MOSAIC (ANR-12-AGRO-005). The authors acknowledge the support of CNRS and INRA for the Observatory ORE-AgrHys, and the support of AllEnvi for the Observatory SOERE-RBV.

\section{References}

Aciego Pietri, J.C., Brookes, P.C., 2009. Substrate inputs and pH as factors controlling microbial biomass, activity and community structure in an arable soil. Soil Biol. Biochem. 41, 1396-1405. https://doi.org/10.1016/J.SOILBIO.2009.03.017

Acosta-Martínez, V., Dowd, S., Sun, Y., Allen, V., 2008. Tag-encoded pyrosequencing analysis of bacterial diversity in a single soil type as affected by management and land use. Soil Biol. Biochem. 40, 2762-2770. https://doi.org/10.1016/J.SOILBIO.2008.07.022

AFNOR, 2012. ISO 10930. Soil quality - Measurement of the stability of soil aggregates subjected to the action of water -

AFNOR, 2003. NF X31-107. Soil Quality - Particle Size Determination by Sedimentation - Pipette Method.

AFNOR, 1998. NF ISO 13878. Soil Quality — Determination of Total Nitrogen Content by Dry Combustion ("Elemental Analysis"). 
AFNOR, 1995. NF ISO 10694. Soil Quality — Determination of Organic and Total Carbon after Dry Combustion (Elementary Analysis).

Banerjee, S., Kirkby, C.A., Schmutter, D., Bissett, A., Kirkegaard, J.A., Richardson, A.E., 2016. Network analysis reveals functional redundancy and keystone taxa amongst bacterial and fungal communities during organic matter decomposition in an arable soil. Soil Biol. Biochem. 97, 188198. https://doi.org/10.1016/j.soilbio.2016.03.017

Bastida, F., García, C., Fierer, N., Eldridge, D.J., Bowker, M.A., Abades, S., Alfaro, F.D., Asefaw Berhe, A., Cutler, N.A., Gallardo, A., García-Velázquez, L., Hart, S.C., Hayes, P.E., Hernández, T., Hseu, Z.Y., Jehmlich, N., Kirchmair, M., Lambers, H., Neuhauser, S., Peña-Ramírez, V.M., Pérez, C.A., Reed, S.C., Santos, F., Siebe, C., Sullivan, B.W., Trivedi, P., Vera, A., Williams, M.A., Luis Moreno, J., Delgado-Baquerizo, M., 2019. Global ecological predictors of the soil priming effect. Nat. Commun. 10. https://doi.org/10.1038/s41467-019-11472-7Baumann, K., Sanaullah, M., Chabbi, A., Dignac, M.F., Bardoux, G., Steffens, M., Kögel-Knabner, I., Rumpel, C., 2013. Changes in litter chemistry and soil lignin signature during decomposition and stabilisation of $13 \mathrm{C}$ labelled wheat roots in three subsoil horizons. Soil Biol. Biochem. 67, 5561. https://doi.org/10.1016/j.soilbio.2013.07.012

Bernard-Jannin, L., Binet, S., Gogo, S., Leroy, F., Défarge, C., Jozja, N., Zocatelli, R., Perdereau, L., Laggoun-Défarge, F., 2018. Hydrological control of dissolved organic carbon dynamics in a rehabilitated Sphagnum-dominated peatland: a water-table based modelling approach. Hydrol. Earth Syst. Sci. 22, 4907-4920. https://doi.org/10.5194/hess-22-4907-2018

Beven, K.J., Kirby, M.J., 1979. A physically based, variable contributing area model of basin hydrology / Un modèle à base physique de zone d'appel variable de l'hydrologie du bassin versant. Hydrol. Sci. Bull. 24, 43-69. https://doi.org/10.1080/02626667909491834

Bingeman, C.W., Varner, J.E., Martin, W.P., 1953. The Effect of the Addition of Organic Materials on the Decomposition of an Organic Soil1. Soil Sci. Soc. Am. J. 17, 34. https://doi.org/10.2136/sssaj1953.03615995001700010008x

Blagodatskaya, E., Kuzyakov, Y., 2008. Mechanisms of real and apparent priming effects and their dependence on soil microbial biomass and community structure: Critical review. Biol. Fertil. Soils 45, 115-131.

Bongiorno, G., Bünemann, E.K., Oguejiofor, C.U., Meier, J., Gort, G., Comans, R., Mäder, P., Brussaard, L., de Goede, R., 2019. Sensitivity of labile carbon fractions to tillage and organic matter management and their potential as comprehensive soil quality indicators across pedoclimatic conditions in Europe. Ecol. Indic. 99, 38-50. https://doi.org/10.1016/J.ECOLIND.2018.12.008

Cambardella, C.A., Elliot, E.T., 1992. Particulate soil organic-matter changes across a grassland cultivation sequence. Soil Sci. Soc. Am. J. 56, 777-783.

Chemidlin Prévost-Bouré, N., Dequiedt, S., Thioulouse, J., Lelièvre, M., Saby, N.P.A., Jolivet, C., Arrouays, D., Plassart, P., Lemanceau, P., Ranjard, L., 2014. Similar Processes but Different Environmental Filters for Soil Bacterial and Fungal Community Composition Turnover on a Broad Spatial Scale. PLoS One 9, e111667. https://doi.org/10.1371/journal.pone.0111667

Chen, R., Senbayram, M., Blagodatsky, S., Myachina, O., Dittert, K., Lin, X., Blagodatskaya, E., Kuzyakov, Y., 2014. Soil C and $\mathrm{N}$ availability determine the priming effect: microbial $\mathrm{N}$ mining and stoichiometric decomposition theories. Glob. Chang. Biol. 20, 2356-2367. https://doi.org/10.1111/gcb.12475

Chin, Y.-P., Aiken, G., O’Loughlin, E., 1994. Molecular Weight, Polydispersity, and Spectroscopic Properties of Aquatic Humic Substances. Environ. Sci. Technol. 28, 1853-1858. https://doi.org/10.1021/es00060a015 
Coble, P.G., 1996. Characterization of marine and terrestrial DOM in seawater using excitationemission matrix spectroscopy. Mar. Chem. 51, 325-346. https://doi.org/10.1016/03044203(95)00062-3

Cory, R.M., McKnight, D., 2005. Fluorescence spectroscopy reveals ubiquitous presence of oxidized and reduced quinones in dissolved organic matter. Environ. Sci. Technol. 39, 8142-8149.

Craig, M.E., Pearson, S.M., Fraterrigo, J.M., 2015. Grass invasion effects on forest soil carbon depend on landscape-level land use patterns. Ecology 96, 2265-2279. https://doi.org/10.1890/14-1770.1

Dainard, P.G., Guéguen, C., McDonald, N., Williams, W.J., 2015. Photobleaching of fluorescent dissolved organic matter in Beaufort Sea and North Atlantic Subtropical Gyre. Mar. Chem. 177, 630-637.

de Graaff, M.-A., Jastrow, J.D., Gillette, S., Johns, A., Wullschleger, S.D., 2014. Differential priming of soil carbon driven by soil depth and root impacts on carbon availability. Soil Biol. Biochem. 69, 147-156. https://doi.org/10.1016/J.SOILBIO.2013.10.047

Dequiedt, S., Saby, N.P.A., Lelievre, M., Jolivet, C., Thioulouse, J., Toutain, B., Arrouays, D., Bispo, A., Lemanceau, P., Ranjard, L., 2011. Biogeographical patterns of soil molecular microbial biomass as influenced by soil characteristics and management. Glob. Ecol. Biogeogr. 20, 641652. https://doi.org/10.1111/j.1466-8238.2010.00628.x

Dignac, M.-F., Derrien, D., Barré, P., Barot, S., Cécillon, L., Chenu, C., Chevallier, T., Freschet, G.T., Garnier, P., Guenet, B., Hedde, M., Klumpp, K., Lashermes, G., Maron, P.-A., Nunan, N., Roumet, C., Basile-Doelsch, I., 2017. Increasing soil carbon storage: mechanisms, effects of agricultural practices and proxies. A review. Agron. Sustain. Dev. 37, 14. https://doi.org/10.1007/s13593-017-0421-2

Finley, B.K., Dijkstra, P., Rasmussen, C., Schwartz, E., Mau, R.L., Liu, X.-J.A., van Gestel, N., Hungate, B.A., 2018. Soil mineral assemblage and substrate quality effects on microbial priming. Geoderma 322, 38-47. https://doi.org/10.1016/J.GEODERMA.2018.01.039

Fontaine, S., Mariotti, A., Abbadie, L., 2003. The priming effect of organic matter: a question of microbial competition? Soil Biol. Biochem. 35, 837-843. https://doi.org/10.1016/S00380717(03)00123-8

Fox, J., Weisberg, S., 2011. An \{R $\}$ Companion to Applied Regression, Second. ed. Sage, Thousand Oaks $\{\mathrm{CA}\}$.

Frank, A.B., Liebig, M.A., Hanson, J.D., 2002. Soil carbon dioxide fluxes in northern semiarid grasslands. Soil Biol. Biochem. 34, 1235-1241.

Glover, J.D., Culman, S.W., DuPont, S.T., Broussard, W., Young, L., Mangan, M.E., Mai, J.G., Crews, T.E., DeHaan, L.R., Buckley, D.H., Ferris, H., Turner, R.E., Reynolds, H.L., Wyse, D.L., 2010. Harvested perennial grasslands provide ecological benchmarks for agricultural sustainability. Agric. Ecosyst. Environ. 137, 3-12. https://doi.org/10.1016/j.agee.2009.11.001

Goldfarb, K.C., Karaoz, U., Hanson, C.A., Santee, C.A., Bradford, M.A., Treseder, K.K., Wallenstein, M.D., Brodie, E.L., 2011. Differential Growth Responses of Soil Bacterial Taxa to Carbon Substrates of Varying Chemical Recalcitrance. Front. Microbiol. 2. https://doi.org/10.3389/fmicb.2011.00094

Guenet, B., Camino-Serrano, M., Ciais, P., Tifafi, M., Maignan, F., Soong, J.L., Janssens, I.A., 2018. Impact of priming on global soil carbon stocks. Glob. Chang. Biol. https://doi.org/10.1111/gcb.14069

Guenet, B., Leloup, J., Raynaud, X., Bardoux, G., Abbadie, L., 2010. Negative priming effect on mineralization in a soil free of vegetation for 80 years. Eur. J. Soil Sci. 61, 384-391. https://doi.org/10.1111/j.1365-2389.2010.01234.x 
Guigue, J., Harir, M., Mathieu, O., Lucio, M., Ranjard, L., Lévêque, J., Schmitt-Kopplin, P., 2016. Ultrahigh-resolution FT-ICR mass spectrometry for molecular characterisation of pressurised hot water-extractable organic matter in soils. Biogeochemistry 128, 307-326. https://doi.org/10.1007/s10533-016-0209-5

Guigue, J., Mathieu, O., Lévêque, J., Mounier, S., Laffont, R., Maron, P.A., Navarro, N., Chateau, C., Amiotte-Suchet, P., Lucas, Y., 2014. A comparison of extraction procedures for waterextractable organic matter in soils. Eur. J. Soil Sci. 65, 520-530. https://doi.org/10.1111/ejss.12156

Haines-Young, R., Potschin, M., 2010. The links between biodiversity, ecosystem services and human well-being. Ecosyst. Ecol. a new Synth. 1, 110-139.

Hamer, U., Marschner, B., 2005. Priming effects in different soil types induced by fructose, alanine, oxalic acid and catechol additions. Soil Biol. Biochem. 37, 445-454. https://doi.org/10.1016/J.SOILBIO.2004.07.037

Helgason, B.L., Konschuh, H.J., Bedard-Haughn, A., VandenBygaart, A.J., 2014. Microbial distribution in an eroded landscape: Buried A horizons support abundant and unique communities. Agric. Ecosyst. Environ. 196, 94-102. https://doi.org/10.1016/j.agee.2014.06.029

Hunt, J.F., Ohno, T., 2007. Characterization of fresh and decomposed dissolved organic matter using excitation-emission matrix fluorescence spectroscopy and multiway analysis. J. Agric. Food Chem. 55, 2121-2128. https://doi.org/10.1021/jf063336m

IUSS Working Group WRB, 2015. World Reference Base for Soil Resources 2014, update 2015 International soil classification system for naming soils and creating legends for soil maps., World Soil. ed. FAO, Rome.

Jackson, R.B., Canadell, J., Ehleringer, J.R., Mooney, H.A., Sala, O.E., Schulze, E.D., 1996. A global analysis of root distributions for terrestrial biomes. Oecologia 108, 389-411. https://doi.org/10.1007/bf00333714

Kalbitz, K., Solinger, S., Park, J.-H., Michalzik, B., Matzner, E., 2000. Controls on the dynamics of dissolved organic matter in soils: a review. Soil Sci. 165, 277-304.

Keiluweit, M., Bougoure, J.J., Nico, P.S., Pett-Ridge, J., Weber, P.K., Kleber, M., 2015. Mineral protection of soil carbon counteracted by root exudates. Nat. Clim. Chang. 5, 588-595. https://doi.org/10.1038/nclimate2580

Kirschbaum, M.U.F., 1995. The temperature dependence of soil organic matter decomposition, and the effect of global warming on soil organic C storage. Soil Biol. Biochem. 27, 753-760. https://doi.org/10.1016/0038-0717(94)00242-S

Kuzyakov, Y., 2010. Priming effects: Interactions between living and dead organic matter. Soil Biol. Biochem. 42, 1363-1371. https://doi.org/10.1016/J.SOILBIO.2010.04.003

Kuzyakov, Y., Blagodatskaya, E., 2015. Microbial hotspots and hot moments in soil: Concept \& review. Soil Biol. Biochem. 83, 184-199. https://doi.org/10.1016/J.SOILBIO.2015.01.025

Kuzyakov, Y., Friedel, J.K., Stahr, K., 2000. Review of mechanisms and quantification of priming effects. Soil Biol. Biochem. 32, 1485-1498.

Lal, R., Stewart, B.A., 1990. Advances in Soil Science : Soil Degradation. Springer New York.

Lambert, T., Bouillon, S., Darchambeau, F., Morana, C., Roland, F.A.E., Descy, J.-P., Borges, A. V., 2017. Effects of human land use on the terrestrial and aquatic sources of fluvial organic matter in a temperate river basin (The Meuse River, Belgium). Biogeochemistry 136, 191-211. https://doi.org/10.1007/s10533-017-0387-9

Le Bissonnais, Y., 1996. Aggregate stability and assessment of soil crustability and erodibility: I. 
Theory and methodology - Stabilité structurale et évaluation de la sensibilité des sols à la battance et à l'érosion: I: Théorie et méthologie. Eur. J. Soil Sci. 47, 425-437. https://doi.org/10.1111/j.1365-2389.1996.tb01843.x

Le Guillou, C., Chemidlin Prévost-Bouré, N., Karimi, B., Akkal-Corfini, N., Dequiedt, S., Nowak, V., Terrat, S., Menasseri-Aubry, S., Viaud, V., Maron, P.-A., Ranjard, L., 2018. Tillage intensity and pasture in rotation effectively shape soil microbial communities at a landscape scale. Microbiologyopen e00676. https://doi.org/10.1002/mbo3.676

Lemaire, G., Gastal, F., Franzluebbers, A., Chabbi, A., 2015. Grassland-Cropping Rotations: An Avenue for Agricultural Diversification to Reconcile High Production with Environmental Quality. Environ. Manage. https://doi.org/10.1007/s00267-015-0561-6

Longdoz, B., Yernaux, M., Aubinet, M., 2000. Soil $\mathrm{CO}_{2}$ efflux measurements in a mixed forest: impact of chamber disturbances, spatial variability and seasonal evolution. Glob. Chang. Biol. 6, 907-917. https://doi.org/10.1046/j.1365-2486.2000.00369.x

Louis, B.P., Maron, P.-A., Menasseri-Aubry, S., Sarr, A., Lévêque, J., Mathieu, O., Jolivet, C., Leterme, P., Viaud, V., 2016. Microbial Diversity Indexes Can Explain Soil Carbon Dynamics as a Function of Carbon Source. PLoS One 11, e0161251. https://doi.org/10.1371/journal.pone.0161251

Lumley, T., 2017. leaps: Regression Subset Selection. Based on Fortran code by Alan Miller.

Maron, P.A., Sarr, A., Kaisermann, A., Lévêque, J., Mathieu, O., Guigue, J., Karimi, B., Bernard, L., Dequiedt, S., Terrat, S., Chabbi, A., Ranjard, L., 2018. High microbial diversity promotes soil ecosystem functioning. Appl. Environ. Microbiol. 84. https://doi.org/10.1128/AEM.02738-17

Minasny, B., Malone, B.P., McBratney, A.B., Angers, D.A., Arrouays, D., Chambers, A., Chaplot, V., Chen, Z.-S., Cheng, K., Das, B.S., Field, D.J., Gimona, A., Hedley, C.B., Hong, S.Y., Mandal, B., Marchant, B.P., Martin, M., McConkey, B.G., Mulder, V.L., O’Rourke, S., Richer-de-Forges, A.C., Odeh, I., Padarian, J., Paustian, K., Pan, G., Poggio, L., Savin, I., Stolbovoy, V., Stockmann, U., Sulaeman, Y., Tsui, C.-C., Vågen, T.-G., van Wesemael, B., Winowiecki, L., 2017. Soil carbon 4 per mille. Geoderma 292, 59-86. https://doi.org/10.1016/J.GEODERMA.2017.01.002

Murphy, K.R., Stedmon, C.A., Graeber, D., Bro, R., 2013. Fluorescence spectroscopy and multi-way techniques. PARAFAC. Anal. Methods 5, 6557. https://doi.org/10.1039/c3ay41160e

Murphy, K.R., Stedmon, C.A., Wenig, P., Bro, R., 2014. OpenFluor- an online spectral library of auto-fluorescence by organic compounds in the environment. Anal. Methods 6, 658-661. https://doi.org/10.1039/C3AY41935E

Oksanen, J., Blanchet, F.G., Friendly, M., Kindt, R., Legendre, P., McGlinn, D., Minchin, P.R., O’Hara, R.B., Simpson, G.L., Solymos, P., Stevens, M.H.H., Szoecs, E., Wagner, H., 2018. vegan: Community Ecology Package.

Osburn, C.L., Handsel, L.T., Mikan, M.P., Paerl, H.W., Montgomery, M.T., 2012. Fluorescence Tracking of Dissolved and Particulate Organic Matter Quality in a River-Dominated Estuary. Environ. Sci. Technol. 46, 8628-8636. https://doi.org/10.1021/es3007723

Panettieri, M., Knicker, H., Murillo, J.M., Madejón, E., Hatcher, P.G., 2014. Soil organic matter degradation in an agricultural chronosequence under different tillage regimes evaluated by organic matter pools, enzymatic activities and CPMAS 13C NMR. Soil Biol. Biochem. 78, 170181. https://doi.org/10.1016/j.soilbio.2014.07.021

Panettieri, M., Rumpel, C., Dignac, M.-F., Chabbi, A., 2017. Does grassland introduction into cropping cycles affect carbon dynamics through changes of allocation of soil organic matter within aggregate fractions? Sci. Total Environ. 576. https://doi.org/10.1016/j.scitotenv.2016.10.073 
Pielou, E.C., 1966. The measurement of diversity in different types of biological collections. J. Theor. Biol. 13, 131-144. https://doi.org/10.1016/0022-5193(66)90013-0

Plassart, P., Terrat, S., Thomson, B., Griffiths, R., Dequiedt, S., Lelievre, M., Regnier, T., Nowak, V., Bailey, M., Lemanceau, P., Bispo, A., Chabbi, A., Maron, P.-A., Mougel, C., Ranjard, L., 2012. Evaluation of the ISO Standard 11063 DNA Extraction Procedure for Assessing Soil Microbial Abundance and Community Structure. PLoS One 7, e44279. https://doi.org/10.1371/journal.pone.0044279

Potthoff, M., Jackson, L.E., Steenwerth, K.L., Ramirez, I., Stromberg, M.R., Rolston, D.E., 2005. Soil biological and chemical properties in restored perennial grassland in California. Restor. Ecol. 13, $61-73$.

Powlson, D.S., Gregory, P.J., Whalley, W.R., Quinton, J.N., Hopkins, D.W., Whitmore, A.P., Hirsch, P.R., Goulding, K.W.T., 2011. Soil management in relation to sustainable agriculture and ecosystem services. Food Policy 36, S72-S87. https://doi.org/10.1016/J.FOODPOL.2010.11.025

Rasse, D.P., Rumpel, C., Dignac, M.F., 2005. Is soil carbon mostly root carbon? Mechanisms for a specific stabilisation. Plant Soil 269, 341-356. https://doi.org/10.1007/s11104-004-0907-y

Razanamalala, K., Razafimbelo, T., Maron, P.-A., Ranjard, L., Chemidlin, N., Lelièvre, M., Dequiedt, S., Ramaroson, V.H., Marsden, C., Becquer, T., Trap, J., Blanchart, E., Bernard, L., 2018. Soil microbial diversity drives the priming effect along climate gradients: a case study in Madagascar. ISME J. 12, 451-462. https://doi.org/10.1038/ismej.2017.178

Romero, C.M., Engel, R.E., D’Andrilli, J., Chen, C., Zabinski, C., Miller, P.R., Wallander, R., 2017. Bulk optical characterization of dissolved organic matter from semiarid wheat-based cropping systems. Geoderma 306, 40-49. https://doi.org/10.1016/j.geoderma.2017.06.029

Roth, V.-N., Dittmar, T., Gaupp, R., Gleixner, G., 2014. Ecosystem-Specific Composition of Dissolved Organic Matter. Vadose Zo. J. 13, 0. https://doi.org/10.2136/vzj2013.09.0162

Shahbaz, M., Kumar, A., Kuzyakov, Y., Börjesson, G., Blagodatskaya, E., 2018. Interactive priming effect of labile carbon and crop residues on SOM depends on residue decomposition stage: Three-source partitioning to evaluate mechanisms. Soil Biol. Biochem. 126, 179-190. https://doi.org/10.1016/J.SOILBIO.2018.08.023

Shange, R.S., Ankumah, R.O., Ibekwe, A.M., Zabawa, R., Dowd, S.E., 2012. Distinct Soil Bacterial Communities Revealed under a Diversely Managed Agroecosystem. PLoS One 7, e40338. https://doi.org/10.1371/journal.pone.0040338

Sheather, S., 2009. A Modern Approach to Regression with R, Springer Texts in Statistics. Springer New York, New York, NY. https://doi.org/10.1007/978-0-387-09608-7

Six, J., Elliott, E.T., Paustian, K., Doran, J.W., 1998. Aggregation and soil organic matter accumulation in cultivated and native grassland soils. Soil Sci. Soc. Am. J. 62, 1367-1377.

Smith, P., 2014. Do grasslands act as a perpetual sink for carbon? Glob. Chang. Biol. https://doi.org/10.1111/gcb.12561

Solomon, D., Lehman, J., Kinyangi, J., Amelung, W., Lobe, I., Pell, A., Riha, S., Ngoze, S., Verchot, L., Mbugua, D., Skjemstad, J., Schafer, T., 2007. Long-term impacts of anthropogenic perturbations on dynamics and speciation of organic carbon in tropical forest and subtropical grassland ecosystems. Glob. Chang. Biol. 13, 511-530. https://doi.org/10.1111/j.13652486.2006.01304.x

Søndergaard, M., Stedmon, C.A., Borch, N.H., 2003. Fate of terrigenous dissolved organic matter (DOM) in estuaries: Aggregation and bioavailability. Ophelia 57, 161-176. https://doi.org/10.1080/00785236.2003.10409512 
Sparling, G.P., 1992. Ratio of microbial biomass carbon to soil organic carbon as a sensitive indicator of changes in soil organic matter. Aust. J. Soil Res. 30, 195-207.

Stedmon, C.A., Markager, S., 2005. Resolving the variability in dissolved organic matter fluorescence in a temperate estuary and its catchment using PARAFAC analysis. Limnol. Oceanogr. 50, 686697. https://doi.org/10.4319/lo.2005.50.2.0686

Stubbins, A., Lapierre, J.-F., Berggren, M., Prairie, Y.T., Dittmar, T., del Giorgio, P.A., 2014. What's in an EEM? Molecular Signatures Associated with Dissolved Organic Fluorescence in Boreal Canada. Environ. Sci. Technol. 48, 10598-10606. https://doi.org/10.1021/es502086e

Swinton, S.M., Lupi, F., Robertson, G.P., Hamilton, S.K., 2007. Ecosystem services and agriculture: Cultivating agricultural ecosystems for diverse benefits. Ecol. Econ.

https://doi.org/10.1016/j.ecolecon.2007.09.020

Tabachnick, B.G., Fidell, L.S., 2007. Using multivariate statistics, 5th ed., Using multivariate statistics, 5th ed. Allyn \& Bacon/Pearson Education, Boston, MA.

Tardy, V., Spor, A., Mathieu, O., Lévèque, J., Terrat, S., Plassart, P., Regnier, T., Bardgett, R.D., van der Putten, W.H., Roggero, P.P., Seddaiu, G., Bagella, S., Lemanceau, P., Ranjard, L., Maron, P.-A., 2015. Shifts in microbial diversity through land use intensity as drivers of carbon mineralization in soil. Soil Biol. Biochem. 90, 204-213. https://doi.org/10.1016/J.SOILBIO.2015.08.010

Terrat, S., Christen, R., Dequiedt, S., Lelièvre, M., Nowak, V., Regnier, T., Bachar, D., Plassart, P., Wincker, P., Jolivet, C., Bispo, A., Lemanceau, P., Maron, P.-A., Mougel, C., Ranjard, L., 2012. Molecular biomass and MetaTaxogenomic assessment of soil microbial communities as influenced by soil DNA extraction procedure. Microb. Biotechnol. 5, 135-141. https://doi.org/10.1111/j.1751-7915.2011.00307.x

Tiessen, H., Cuevas, E., Chacon, P., 1994. The role of soil organic matter in sustaining soil fertility. Nature 371, 783-785. https://doi.org/10.1038/371783a0

van Eekeren, N., Bommelé, L., Bloem, J., Schouten, T., Rutgers, M., de Goede, R., Reheul, D., Brussaard, L., 2008. Soil biological quality after 36 years of ley-arable cropping, permanent grassland and permanent arable cropping. Appl. Soil Ecol. 40, 432-446. https://doi.org/10.1016/J.APSOIL.2008.06.010

Viaud, V., Santillàn-Carvantes, P., Akkal-Corfini, N., Le Guillou, C., Prévost-Bouré, N.C., Ranjard, L., Menasseri-Aubry, S., 2018. Landscape-scale analysis of cropping system effects on soil quality in a context of crop-livestock farming. Agric. Ecosyst. Environ. 265, 166-177. https://doi.org/10.1016/J.AGEE.2018.06.018

Walter, C., Curmi, P., 1998. Les sols du bassin-versant du Coët Dan: organisation, variabilité spatiale et cartographie, in: Agriculture Intensive et Qualité Des Eaux. INRA Editions, Paris, France, pp. 85-108.

Walz, J., Knoblauch, C., Böhme, L., Pfeiffer, E.M., 2017. Regulation of soil organic matter decomposition in permafrost-affected Siberian tundra soils - Impact of oxygen availability, freezing and thawing, temperature, and labile organic matter. Soil Biol. Biochem. 110, 34-43. https://doi.org/10.1016/j.soilbio.2017.03.001

Wei, T., Simko, V., 2017. R package "corrplot": Visualization of a Correlation Matrix.

Weishaar, J.L., Aiken, G.R., Bergamaschi, B.A., Fram, M.S., Fujii, R., Mopper, K., 2003. Evaluation of Specific Ultraviolet Absorbance as an Indicator of the Chemical Composition and Reactivity of Dissolved Organic Carbon. https://doi.org/10.1021/ES030360X

Wheeler, K.I., Levia, D.F., Hudson, J.E., 2017. Tracking senescence-induced patterns in leaf litter leachate using parallel factor analysis (PARAFAC) modeling and self-organizing maps. J. 
910 Wickham, H., 2009. ggplot2: Elegant Graphics for Data Analysis. Springer-Verlag New York.

911 Yamashita, Y., Kloeppel, B.D., Knoepp, J., Zausen, G.L., Jaffé, R., 2011. Effects of Watershed History on Dissolved Organic Matter Characteristics in Headwater Streams. Ecosystems 14, 
916 Table 1 Descriptive statistic of environmental parameters for the 88 soil samples from MOSAIC

917 project.

\begin{tabular}{|c|c|c|c|c|c|c|c|}
\hline Variable & Units & Minimum & $\begin{array}{c}1^{\text {st }} \\
\text { Quartile }\end{array}$ & Median & Mean & $\begin{array}{c}3^{\text {rd }} \\
\text { Quartile } \\
\end{array}$ & Maximum \\
\hline Priming Effect DW soil ${ }^{\text {a }}$ & $\mu g C g^{-1} D W$ soil & 7.97 & 48.0 & 56.5 & 59.6 & 66.8 & 147.5 \\
\hline Priming Effect/TOC ${ }^{\text {a }}$ & $m g C g^{-1} T O C$ & 0.24 & 1.98 & 2.48 & 2.50 & 2.96 & 4.96 \\
\hline Control Soil $\mathrm{CO}_{2}{ }^{\mathrm{a}}$ & $\mu g C-C_{2} g^{-1} D W$ soil & 86 & 128 & 154 & 182 & 191 & 726 \\
\hline Amended Soil $\mathrm{CO}_{2}{ }^{\mathrm{a}}$ & $\mu g \mathrm{C}-\mathrm{CO}_{2} g^{-1} \mathrm{DW}$ soil & 808 & 915 & 969 & 995 & 1048 & 1522 \\
\hline Control Soil $\mathrm{CO}_{2}$ Norm TOC ${ }^{\text {a }}$ & $m g C-\mathrm{CO}_{2} g^{-1} \mathrm{TOC}$ & 4.0 & 5.6 & 6.7 & 7.1 & 8.2 & 15.7 \\
\hline Amended Soil $\mathrm{CO}_{2}$ Norm TOC $^{\mathrm{a}}$ & $m g C-\mathrm{CO}_{2} g^{-1} \mathrm{TOC}$ & 21.9 & 35.0 & 41.3 & 41.8 & 45.7 & 78.1 \\
\hline Mineralized litter $\mathrm{C}_{\text {org }}$ & $\%$ of litter $C_{\text {org }}$ added & 29.5 & 33.6 & 34.9 & 35.5 & 37.4 & 42.9 \\
\hline TOC & $m g C g^{-1} D W$ soil & 13.4 & 21.0 & 23.8 & 25.2 & 26.0 & 69.6 \\
\hline $\mathbf{T N}$ & $m g N g^{-1} D W$ soil & 1.6 & 2.1 & 2.3 & 2.5 & 2.5 & 6.4 \\
\hline TOC/TN & & 8.64 & 9.61 & 10.1 & 10.2 & 10.8 & 11.6 \\
\hline Soil $\delta^{13} \mathrm{C}$ signature & $\% o$ & -29.5 & -27.0 & -26.1 & -26.3 & -25.3 & -24.2 \\
\hline WEOC DW soil & $m g$ WEOC $g^{-1} D W$ soil & 0.25 & 0.41 & 0.48 & 0.52 & 0.53 & 1.60 \\
\hline WEOC/TOC & $m g$ WEOC $g^{-1}$ TOC & 8.1 & 18.3 & 20.4 & 20.9 & 22.1 & 36.9 \\
\hline WEOC $\delta^{13} \mathrm{C}$ signature & $\%$ & -29.9 & -26.0 & -25.2 & -25.2 & -23.8 & -22.7 \\
\hline SUVA & $\operatorname{lmg} C^{-1} m^{-1}$ & 0.013 & 0.021 & 0.023 & 0.023 & 0.025 & 0.045 \\
\hline Fluo CP1 & $R U m g^{-1}$ WEOC & 0.93 & 1.62 & 1.84 & 1.91 & 2.18 & 3.22 \\
\hline Fluo CP2 & $R U m g^{-1} W E O C$ & 0.73 & 1.22 & 1.42 & 1.50 & 1.77 & 2.68 \\
\hline Fluo CP3 & $R U \mathrm{mg}^{-1}$ WEOC & 0.26 & 0.51 & 0.58 & 0.57 & 0.64 & 0.91 \\
\hline Microbial biomass DW soil & $m g$ DNA $g^{-1} D W$ Soil & 13.3 & 35.7 & 51.4 & 58.1 & 71.4 & 251.7 \\
\hline Microbial biomass/TOC & $m g$ DNA $g^{-1}$ TOC & 0.56 & 1.46 & 2.21 & 2.32 & 2.83 & 6.055 \\
\hline Richness_b & Number of OTUs & 573 & 730 & 754 & 755 & 786 & 853 \\
\hline Evenness_b & $J^{\prime}$ Index & 0.80 & 0.86 & 0.86 & 0.86 & 0.88 & 0.89 \\
\hline Richness_f & Number of OTUs & 235 & 419 & 462 & 473 & 527 & 742 \\
\hline Evenness_f & $J^{\prime}$ Index & 0.55 & 0.64 & 0.67 & 0.66 & 0.69 & 0.74 \\
\hline MWD & $m m$ & 0.51 & 1.20 & 1.73 & 1.83 & 2.33 & 3.37 \\
\hline Bulk Density & $\mathrm{g} \mathrm{cm}^{-3}$ & 0.52 & 1.05 & 1.14 & 1.148 & 1.26 & 1.53 \\
\hline Clay & $m g g^{-1}$ soil & 135 & 165 & 172 & 178 & 181 & 356 \\
\hline Silt & $m g g^{-1}$ soil & 511 & 643 & 673 & 668 & 702 & 744 \\
\hline Sand & $m g g^{-1}$ soil & 77 & 128 & 148 & 154 & 173 & 255 \\
\hline Altitude & $M$ & 80.7 & 113.0 & 123.4 & 121.1 & 131.5 & 137.6 \\
\hline Hydromorphy & & 0 & 0 & 0 & 0.24 & 0 & 1.00 \\
\hline Beven's Index & & 2.10 & 3.20 & 3.80 & 4.10 & 4.30 & 17.0 \\
\hline Soil pH & & 4.80 & 5.82 & 6.04 & 6.02 & 6.25 & 7.23 \\
\hline Olsen P & $m g g^{-1}$ soil & 0.02 & 0.16 & 0.14 & 0.15 & 0.195 & 0.33 \\
\hline $\mathrm{Cu}$ & $m g \mathrm{~kg}^{-1}$ soil & 1.15 & 3.51 & 4.92 & 5.48 & 7.33 & 14.30 \\
\hline $\mathrm{Si}$ & $m g \mathrm{~kg}^{-1}$ soil & 0.03 & 0.04 & 0.05 & 0.05 & 0.06 & 0.09 \\
\hline Al & $m g \mathrm{~kg}^{-1}$ soil & 0.16 & 0.25 & 0.30 & 0.31 & 0.37 & 0.49 \\
\hline $\mathbf{F e}$ & $m g \mathrm{~kg}^{-1}$ soil & 0.34 & 0.47 & 0.50 & 0.54 & 0.58 & 1.31 \\
\hline Grassland Frequency & & 0 & 0 & 0.10 & 0.28 & 0.60 & 1.00 \\
\hline No. cropped species b & & 1.00 & 3.00 & 3.00 & 3.61 & 4.25 & 8.00 \\
\hline Crop Litter & $M g C h a^{-1} y^{-1}$ & 0 & 2.71 & 3.16 & 3.15 & 4.18 & 4.83 \\
\hline Manure & $M g C h a^{-1} y^{-1}$ & 0 & 0.34 & 0.61 & 0.63 & 0.88 & 1.78 \\
\hline
\end{tabular}

${ }^{\mathbf{a}}$ Cumulative values obtained after 80 days of soil incubation in microcosms

$919{ }^{\mathbf{b}}$ For permanent grassland, number of cropped species was assumed to be 1, not taking into account species

920 diversity within prairie. 
923

924

925

926

927

928

929

930

931

932

933

934

935

936

937

938

939

940

941

942

943

944

945

946

947

948

949

\section{Figure Captions}

Figure 1 Representation of WEOM fluorescence PARAFAC components in excitation-emission matrices. All components were previously described as humic-like components in the literature and identified in soil DOM, as well as in natural waters. (see the text for details)

Figure 2 Correlation heatmap of Spearman's correlation of all measured parameters. Size and color of the circles are proportional to the $r_{s}$ coefficient of correlation

Figure 3 Box and whisker plots of the chemical and edaphological parameters of sampled soils.

Cropland ( $n=42)$; LO: low frequency grassland $(n=13)$; MI: mid-frequency grassland $(n=13)$; HI: high-frequency grassland ( $n=13)$; Permanent Grassland $(n=7)$. Treatments with identified by different letters are significantly different. Capital letters are used to highlight significance levels satisfying Bonferroni's correction $(p<0.005)$. Lowercase letters indicate significance levels at $p<0.05$. Circles represent outliers

Figure 4 Box and whisker plots of the priming effect and biological parameters of sampled soils. Cropland ( $n=42)$; LO: low frequency grassland ( $n=13)$; MI: mid-frequency grassland $(n=13)$; HI: high-frequency grassland ( $n=13)$; Permanent Grassland $(n=7)$. Treatments with identified by different letters are significantly different. Capital letters are used to highlight significance levels satisfying Bonferroni's correction $(p<0.005)$. Lowercase letters indicate significance levels at $\mathrm{p}<0.05$. Circles represent outliers

Figure 5 Outputs of the two variance partitioning models for (i) priming effect per g of soil (PE-DW) and (ii) priming effect per g of TOC (PE/TOC). HI: high-frequency grassland; MI: mid-frequency grassland; LO: low-frequency grassland. Significance levels: $* * \mathrm{p}<0.001,{ }^{*} \mathrm{p}<0.05,{ }^{\circ} \mathrm{p}<0.1$. (+) and (-) represent positive or negative coefficients of relation between modeled variables and descriptors. 
950 df: degrees of freedom.

$951+$ :variance assigned to interactions for Priming Effect/DW soil model had a negative value of $-6.33 \%$, 952 see text for more details 
Table 1 Descriptive statistic of environmental parameters for the 88 soil samples from MOSAIC project

\begin{tabular}{|c|c|c|c|c|c|c|c|}
\hline Variable & Units & Minimum & $\begin{array}{c}1^{\text {st }} \\
\text { Quartile } \\
\end{array}$ & Median & Mean & $\begin{array}{c}3^{\text {rd }} \\
\text { Quartile } \\
\end{array}$ & Maximum \\
\hline Priming Effect $D W$ soil $^{\text {a }}$ & $\mu g C g^{-1} D W$ soil & 7.97 & 48.0 & 56.5 & 59.6 & 66.8 & 147.5 \\
\hline Priming Effect/TOC ${ }^{\text {a }}$ & $m g C g^{-1} T O C$ & 0.24 & 1.98 & 2.48 & 2.50 & 2.96 & 4.96 \\
\hline Control Soil $\mathrm{CO}_{2}{ }^{\mathrm{a}}$ & $\mu g C-\mathrm{CO}_{2} g^{-1} \mathrm{DW}$ soil & 86 & 128 & 154 & 182 & 191 & 726 \\
\hline Amended Soil $\mathrm{CO}_{2}{ }^{\mathrm{a}}$ & $\mu g C-C_{2} g^{-1} D W$ soil & 808 & 915 & 969 & 995 & 1048 & 1522 \\
\hline Control Soil $\mathrm{CO}_{2}$ Norm TOC & $m g \mathrm{C}-\mathrm{CO}_{2} g^{-1} \mathrm{TOC}$ & 4.0 & 5.6 & 6.7 & 7.1 & 8.2 & 15.7 \\
\hline Amended Soil $\mathrm{CO}_{2}$ Norm TOC ${ }^{\text {a }}$ & $m g C-\mathrm{CO}_{2} g^{-1} \mathrm{TOC}$ & 21.9 & 35.0 & 41.3 & 41.8 & 45.7 & 78.1 \\
\hline Mineralized litter $\mathbf{C}_{\text {org }}$ & $\%$ of litter $C_{\text {org }}$ added & 29.5 & 33.6 & 34.9 & 35.5 & 37.4 & 42.9 \\
\hline TOC & $m g C g^{-1} D W$ soil & 13.4 & 21.0 & 23.8 & 25.2 & 26.0 & 69.6 \\
\hline $\mathbf{T N}$ & $m g N g^{-1} D W$ soil & 1.6 & 2.1 & 2.3 & 2.5 & 2.5 & 6.4 \\
\hline TOC/TN & & 8.64 & 9.61 & 10.1 & 10.2 & 10.8 & 11.6 \\
\hline Soil $\delta^{13} \mathrm{C}$ signature & $\%$ & -29.5 & -27.0 & -26.1 & -26.3 & -25.3 & -24.2 \\
\hline WEOC DW soil & $m g$ WEOC $g^{-1} D W$ soil & 0.25 & 0.41 & 0.48 & 0.52 & 0.53 & 1.60 \\
\hline WEOC/TOC & $m g$ WEOC $g^{-1}$ TOC & 8.1 & 18.3 & 20.4 & 20.9 & 22.1 & 36.9 \\
\hline WEOC $\delta^{13} \mathrm{C}$ signature & $\%$ & -29.9 & -26.0 & -25.2 & -25.2 & -23.8 & -22.7 \\
\hline SUVA & $\operatorname{lmg} C^{-1} m^{-1}$ & 0.013 & 0.021 & 0.023 & 0.023 & 0.025 & 0.045 \\
\hline Fluo CP1 & $R U m^{-1} W E O C$ & 0.93 & 1.62 & 1.84 & 1.91 & 2.18 & 3.22 \\
\hline Fluo CP2 & $R U m g^{-1} W E O C$ & 0.73 & 1.22 & 1.42 & 1.50 & 1.77 & 2.68 \\
\hline Fluo CP3 & $R U m g^{-1} W E O C$ & 0.26 & 0.51 & 0.58 & 0.57 & 0.64 & 0.91 \\
\hline Microbial biomass DW soil & $m g$ DNA $g^{-1} D W$ Soil & 13.3 & 35.7 & 51.4 & 58.1 & 71.4 & 251.7 \\
\hline Microbial biomass/TOC & $m g$ DNA $g^{-1}$ TOC & 0.56 & 1.46 & 2.21 & 2.32 & 2.83 & 6.055 \\
\hline Richness_b & Number of OTUs & 573 & 730 & 754 & 755 & 786 & 853 \\
\hline Evenness_b & $J^{\prime}$ Index & 0.80 & 0.86 & 0.86 & 0.86 & 0.88 & 0.89 \\
\hline Richness_f & Number of OTUs & 235 & 419 & 462 & 473 & 527 & 742 \\
\hline Evenness_f & J'Index & 0.55 & 0.64 & 0.67 & 0.66 & 0.69 & 0.74 \\
\hline MWD & $m m$ & 0.51 & 1.20 & 1.73 & 1.83 & 2.33 & 3.37 \\
\hline Bulk Density & $\mathrm{g} \mathrm{cm}^{-3}$ & 0.52 & 1.05 & 1.14 & 1.148 & 1.26 & 1.53 \\
\hline Clay & $m g g^{-1}$ soil & 135 & 165 & 172 & 178 & 181 & 356 \\
\hline Silt & $m g g^{-1}$ soil & 511 & 643 & 673 & 668 & 702 & 744 \\
\hline Sand & $m g g^{-1}$ soil & 77 & 128 & 148 & 154 & 173 & 255 \\
\hline Altitude & $M$ & 80.7 & 113.0 & 123.4 & 121.1 & 131.5 & 137.6 \\
\hline Hydromorphy & & 0 & 0 & 0 & 0.24 & 0 & 1.00 \\
\hline Beven's Index & & 2.10 & 3.20 & 3.80 & 4.10 & 4.30 & 17.0 \\
\hline Soil pH & & 4.80 & 5.82 & 6.04 & 6.02 & 6.25 & 7.23 \\
\hline Olsen P & $m g g^{-1}$ soil & 0.02 & 0.16 & 0.14 & 0.15 & 0.195 & 0.33 \\
\hline $\mathrm{Cu}$ & $m g \mathrm{~kg}^{-1}$ soil & 1.15 & 3.51 & 4.92 & 5.48 & 7.33 & 14.30 \\
\hline $\mathbf{S i}$ & $m g \mathrm{~kg}^{-1}$ soil & 0.03 & 0.04 & 0.05 & 0.05 & 0.06 & 0.09 \\
\hline Al & $m g \mathrm{~kg}^{-1}$ soil & 0.16 & 0.25 & 0.30 & 0.31 & 0.37 & 0.49 \\
\hline Fe & $m g \mathrm{~kg}^{-1}$ soil & 0.34 & 0.47 & 0.50 & 0.54 & 0.58 & 1.31 \\
\hline Grassland Frequency & & 0 & 0 & 0.10 & 0.28 & 0.60 & 1.00 \\
\hline No. cropped species b & & 1.00 & 3.00 & 3.00 & 3.61 & 4.25 & 8.00 \\
\hline Crop Litter & $M g C h a^{-1} y^{-1}$ & 0 & 2.71 & 3.16 & 3.15 & 4.18 & 4.83 \\
\hline Manure & $M g C h a^{-1} y^{-1}$ & 0 & 0.34 & 0.61 & 0.63 & 0.88 & 1.78 \\
\hline
\end{tabular}

\footnotetext{
${ }^{\text {a }}$ Cumulative values obtained after 80 days of soil incubation in microcosms

${ }^{\mathbf{b}}$ For permanent grassland, number of cropped species was assumed to be 1, not taking into account species diversity within prairie.
} 
Table S1 Means and standard deviations of the measured parameters not selected as PE descriptors for each land-use

\begin{tabular}{|c|c|c|c|c|c|c|c|c|c|c|c|}
\hline \multirow[b]{2}{*}{ Variables } & \multirow[b]{2}{*}{ Units } & \multicolumn{2}{|c|}{ Cropland } & \multicolumn{2}{|c|}{ LO } & \multicolumn{2}{|c|}{ MI } & \multicolumn{2}{|c|}{ HI } & \multicolumn{2}{|c|}{ Permanent Grassland } \\
\hline & & Mean & $\begin{array}{l}\text { Std. } \\
\text { deviation }\end{array}$ & Mean & $\begin{array}{l}\text { Std. } \\
\text { deviation }\end{array}$ & Mean & $\begin{array}{l}\text { Std. } \\
\text { deviation }\end{array}$ & Mean & $\begin{array}{l}\text { Std. } \\
\text { deviation }\end{array}$ & Mean & $\begin{array}{l}\text { Std. } \\
\text { deviation }\end{array}$ \\
\hline $\begin{array}{l}\text { TN } \\
\text { TOC/TN } \\
\text { Soil } \delta^{13} \mathrm{C} \text { signature } \\
\text { SUVA } \\
\text { WEOC } \delta^{13} \mathrm{C} \text { signature } \\
\text { CP1 } \text { (fluo) } \\
\text { CP2 } \text { (fluo) }^{-}\end{array}$ & $\begin{array}{l}m g \mathrm{Ng}^{-1} \mathrm{DW} \text { soil } \\
\% \text { } \\
\operatorname{lmg} \mathrm{C}^{-1} m^{-1} \\
\% o \\
R U \mathrm{mg}^{-1} \text { WEOC } \\
R U \mathrm{mg}^{-1} \text { WEOC }\end{array}$ & $\begin{array}{l}2.238 \mathbf{a} \\
10.2 \\
-25.68 \\
2.269 \\
-24.44 \\
1.868 \\
1.480 \\
\end{array}$ & $\begin{array}{l}0.272 \\
0.7 \\
0.78 \\
0.242 \\
1.01 \\
0.328 \\
0.295 \\
\end{array}$ & $\begin{array}{l}2.115 \mathbf{a} \\
10.2 \\
-25.44 \\
2.631 \\
-24.04 \\
2.106 \\
1.632 \\
\end{array}$ & $\begin{array}{l}0.321 \\
0.8 \\
0.60 \\
0.750 \\
0.84 \\
0.498 \\
0.447 \\
\end{array}$ & $\begin{array}{l}2.369 \mathbf{a} \\
10.1 \\
-26.71 \\
2.285 \\
-25.70 \\
1.832 \\
1.420 \\
\end{array}$ & $\begin{array}{l}0.170 \\
0.6 \\
0.70 \\
0.316 \\
0.91 \\
0.359 \\
0.343 \\
\end{array}$ & $\begin{array}{l}2.485 \mathbf{a} \\
10.1 \\
-27.42 \\
2.262 \\
-26.76 \\
2.024 \\
1.574 \\
\end{array}$ & $\begin{array}{l}0.555 \\
0.5 \\
0.68 \\
0.491 \\
0.73 \\
0.592 \\
0.565 \\
\end{array}$ & $\begin{array}{l}4.600 \mathbf{b} \\
10.2 \\
-28.78 \\
2.129 \\
-27.65 \\
1.683 \\
1.374 \\
\end{array}$ & $\begin{array}{l}1.130 \\
0.8 \\
0.63 \\
0.718 \\
2.08 \\
0.590 \\
0.485 \\
\end{array}$ \\
\hline $\begin{array}{l}\text { Richness_b } \\
\text { Richness_f } \\
\text { Evenness_f }\end{array}$ & $\begin{array}{l}\text { Number of OTUs } \\
\text { Number of OTUs } \\
\text { J' Index }\end{array}$ & $\begin{array}{l}757 \mathbf{A} \\
451 \mathbf{a} \\
0.654 \mathbf{A} \\
\end{array}$ & $\begin{array}{l}38 \\
90 \\
0.035 \\
\end{array}$ & $\begin{array}{l}773 \mathbf{A B} \\
457 \mathbf{a b} \\
0.648 \mathbf{A} \\
\end{array}$ & $\begin{array}{l}25 \\
63 \\
0.025 \\
\end{array}$ & $\begin{array}{l}770 \mathbf{A B} \\
508 \mathbf{b} \\
0.670 \mathbf{A B}\end{array}$ & $\begin{array}{l}36 \\
91 \\
0.030\end{array}$ & $\begin{array}{l}742 \mathbf{A B} \\
494 \mathbf{a b} \\
0.697 \mathbf{B}\end{array}$ & $\begin{array}{l}48 \\
79 \\
0.023\end{array}$ & $\begin{array}{l}697 \mathbf{A} \\
527 \mathbf{a b} \\
0.693 \mathbf{B}\end{array}$ & $\begin{array}{l}68 \\
107 \\
0.025\end{array}$ \\
\hline $\begin{array}{l}\text { Silt } \\
\text { Sand } \\
\text { Bulk Density } \\
\mathrm{Si} \\
\mathrm{Al} \\
\mathrm{Fe} \\
\mathrm{Cu} \\
\text { Altitude } \\
\text { Beven's index }\end{array}$ & $\begin{array}{l}g \mathrm{~kg}^{-1} \text { soil } \\
\mathrm{g} \mathrm{kg}^{-1} \text { soil } \\
\mathrm{g} \mathrm{cm}^{-3} \\
\mathrm{mg} \mathrm{kg^{-1 }} \text { soil } \\
m g \mathrm{~kg}^{-1} \text { soil } \\
m g \mathrm{~kg}^{-1} \text { soil } \\
m g \mathrm{~kg}^{-1} \text { soil } \\
\mathrm{m}\end{array}$ & $\begin{array}{l}679.0 \text { B } \\
148.9 \\
1.122 \\
0.502 \\
3.29 \\
5.29 \\
5.88 \\
122.1 \mathbf{A B} \\
4.21 \\
\end{array}$ & $\begin{array}{l}32.1 \\
29.1 \\
0.179 \\
0.100 \\
0.75 \\
1.03 \\
3.06 \\
9.9 \\
2.36 \\
\end{array}$ & $\begin{array}{l}667.3 \mathbf{B} \\
164.4 \\
1.212 \\
0.538 \\
3.20 \\
5.28 \\
5.34 \\
116.9 \mathbf{A B} \\
4.01 \\
\end{array}$ & $\begin{array}{l}56.8 \\
46.3 \\
0.127 \\
0.171 \\
0.69 \\
0.70 \\
1.69 \\
9.8 \\
0.73 \\
\end{array}$ & $\begin{array}{l}676.1 \text { B } \\
152.2 \\
1.108 \\
0.438 \\
2.95 \\
5.05 \\
5.45 \\
125.0 \mathbf{A B} \\
4.11 \\
\end{array}$ & $\begin{array}{l}14.7 \\
13.8 \\
0.165 \\
0.087 \\
0.74 \\
1.05 \\
2.64 \\
8.0 \\
1.44 \\
\end{array}$ & $\begin{array}{l}669.7 \mathbf{B} \\
144.4 \\
1.234 \\
0.431 \\
2.66 \\
5.16 \\
5.14 \\
127.4 \mathbf{B} \\
3.62 \\
\end{array}$ & $\begin{array}{l}60.5 \\
32.2 \\
0.161 \\
0.085 \\
0.62 \\
0.59 \\
3.02 \\
8.3 \\
0.78 \\
\end{array}$ & $\begin{array}{l}583.7 \mathbf{A} \\
181.6 \\
1.101 \\
0.443 \\
2.71 \\
7.37 \\
4.02 \\
103.8 \mathbf{A} \\
4.86 \\
\end{array}$ & $\begin{array}{l}37.8 \\
66.4 \\
0.197 \\
0.113 \\
0.69 \\
3.42 \\
2.90 \\
21.1 \\
2.94 \\
\end{array}$ \\
\hline $\begin{array}{l}\text { Manure } \\
\text { No. cropped species* }\end{array}$ & $M g C h a^{-1} y^{-1}$ & $\begin{array}{l}0.725 \mathbf{~ B} \\
3.86 \mathbf{B} \\
\end{array}$ & $\begin{array}{l}0.330 \\
1.07 \\
\end{array}$ & $\begin{array}{l}0.513 \mathbf{A B} \\
4.46 \mathbf{B} \\
\end{array}$ & $\begin{array}{l}0.286 \\
1.85 \\
\end{array}$ & $\begin{array}{l}0.785 \mathbf{~ B} \\
3.92 \mathbf{B} \\
\end{array}$ & $\begin{array}{l}0.387 \\
0.49 \\
\end{array}$ & $\begin{array}{l}0.585 \mathbf{A B} \\
2.92 \mathbf{A B} \\
\end{array}$ & $\begin{array}{l}0.176 \\
0.64 \\
\end{array}$ & $\begin{array}{l}0.136 \mathbf{A} \\
1.00 \mathbf{A} \\
\end{array}$ & 0.269 \\
\hline
\end{tabular}

Significant differences at $p<0.05$ are marked with different lowercase letters. Significant differences at $p<0.005$ are marked with different capital letters.

LO: low-frequency grassland; MI: mid-frequency grassland; HI: high-frequency grassland;

*For permanent grassland, number of cropped species was assumed to be 1 , not taking into account species diversity within prairie. 
Figure 1
Click here to download Figure: Figure 1.pdf

Figure 1
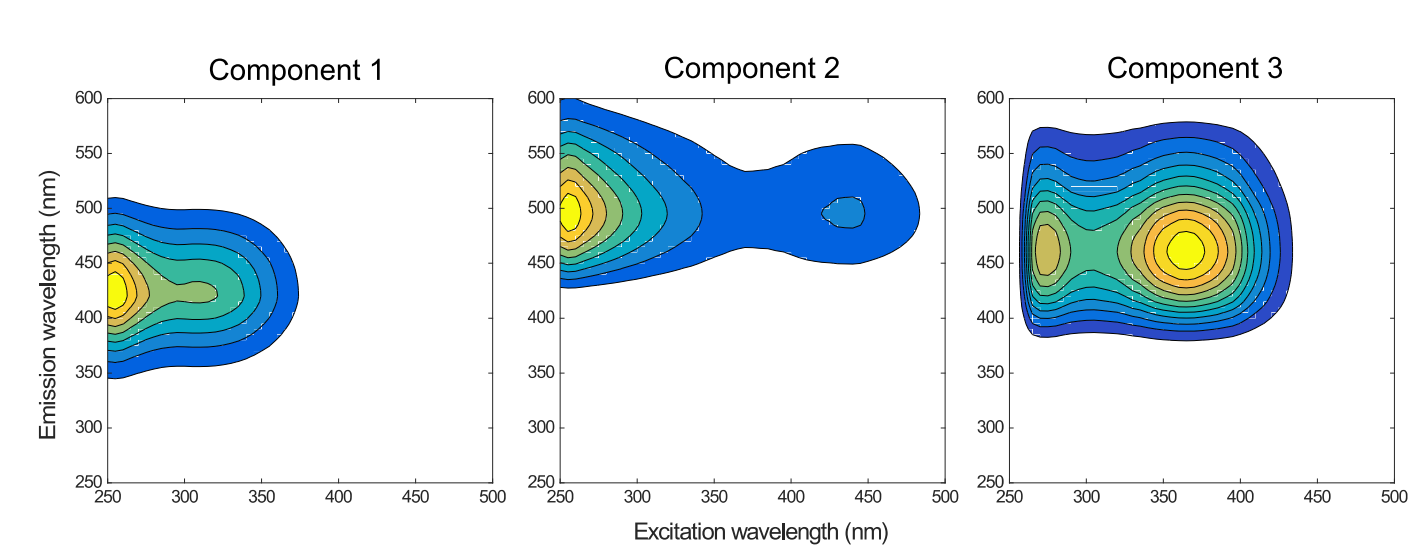
Figure 2

Click here to download Figure: Figure 2.pdf

Figure 2

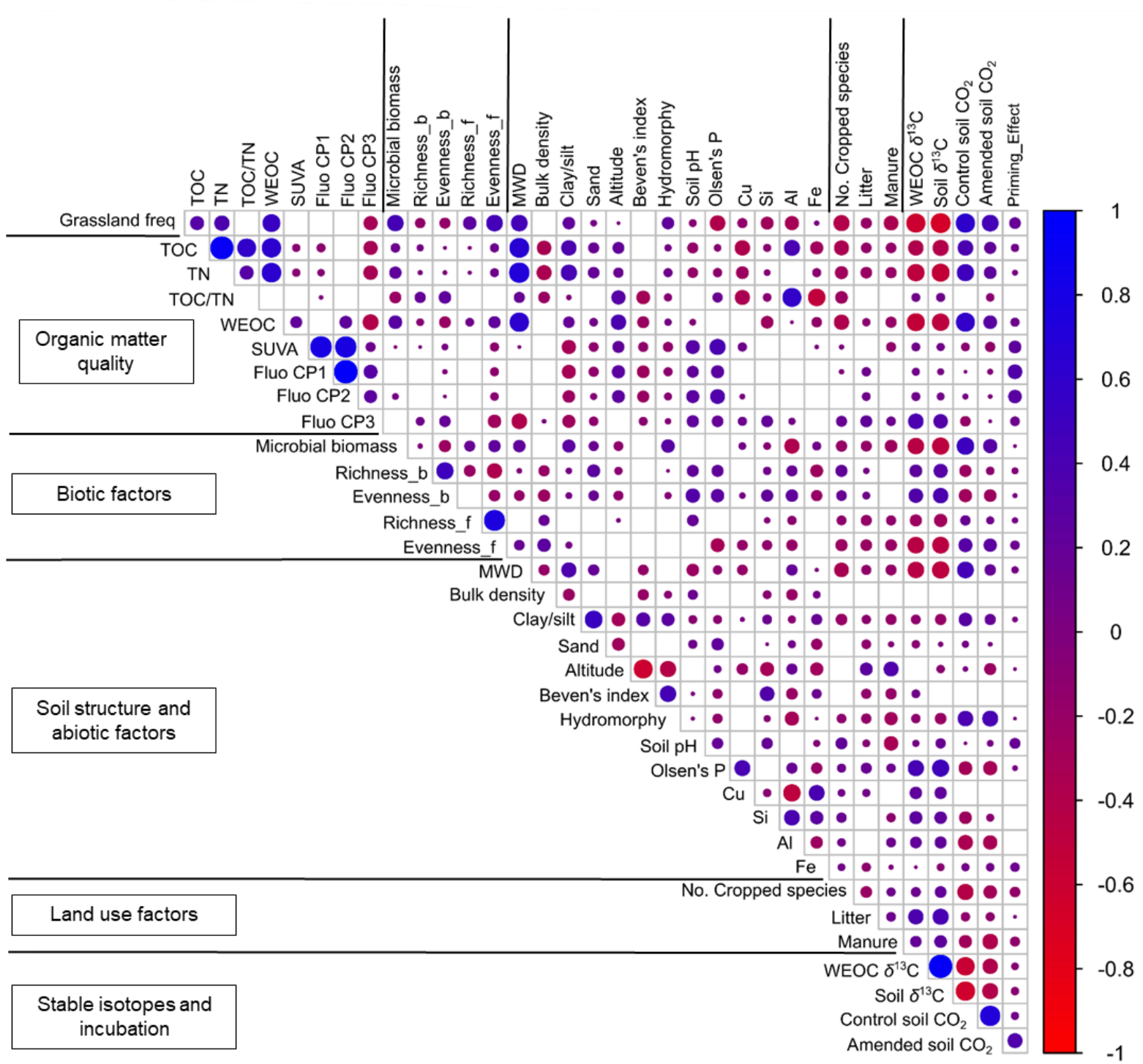


Figurf bgure 3

Click her/A)to download Figf
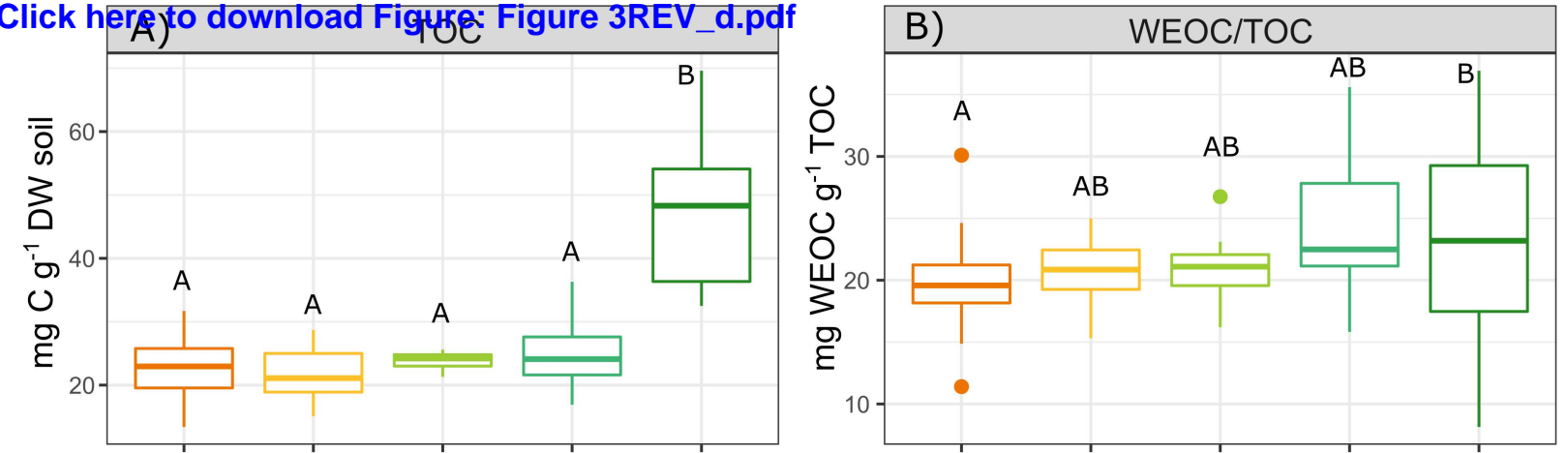

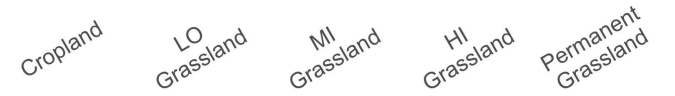
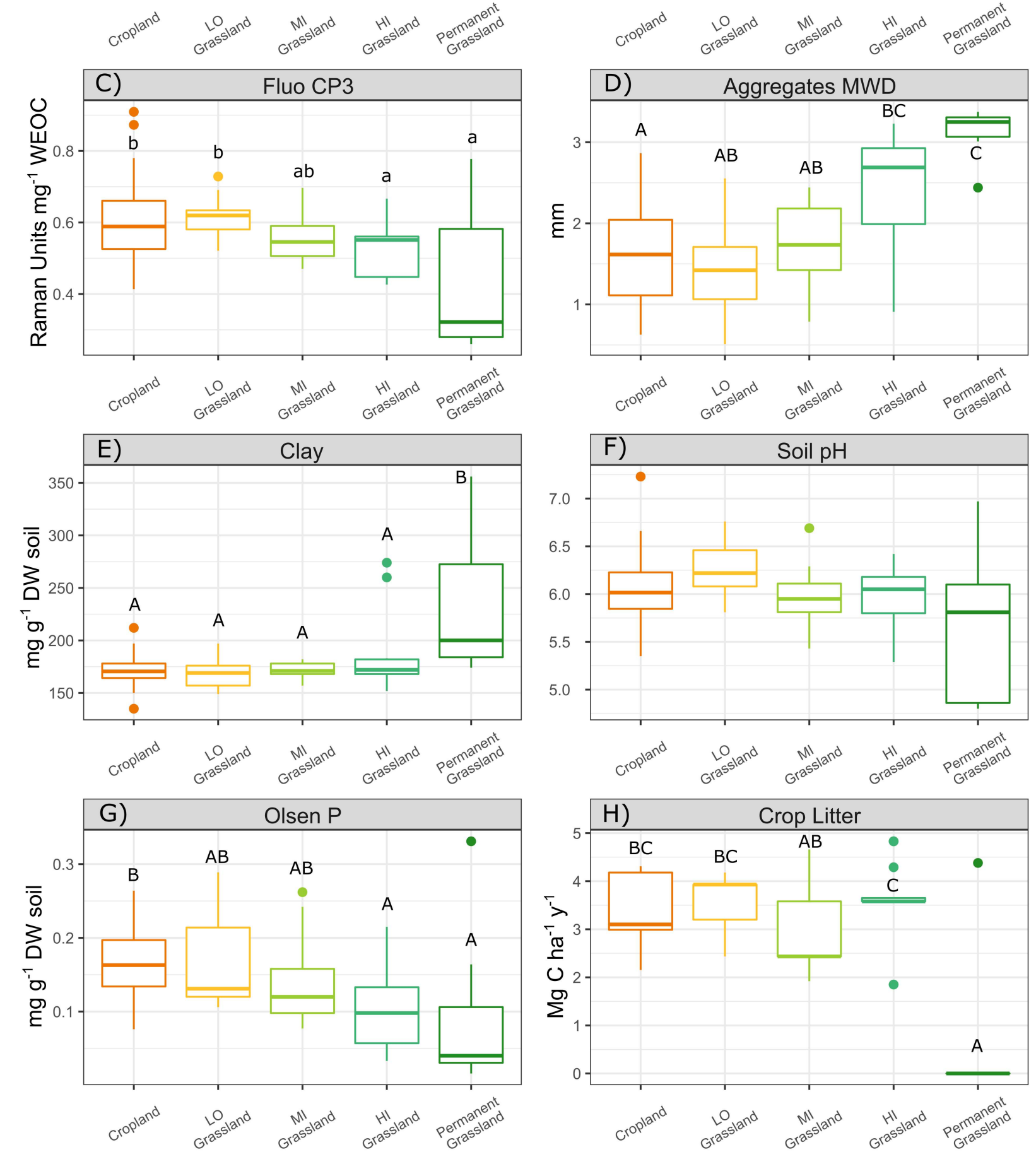

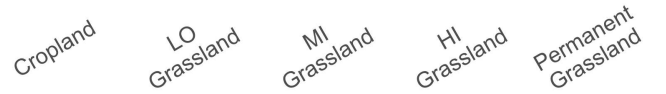

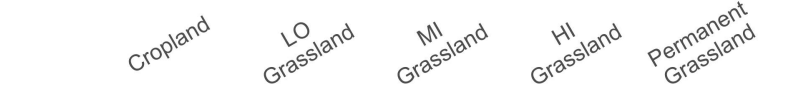




\section{Figure 4}
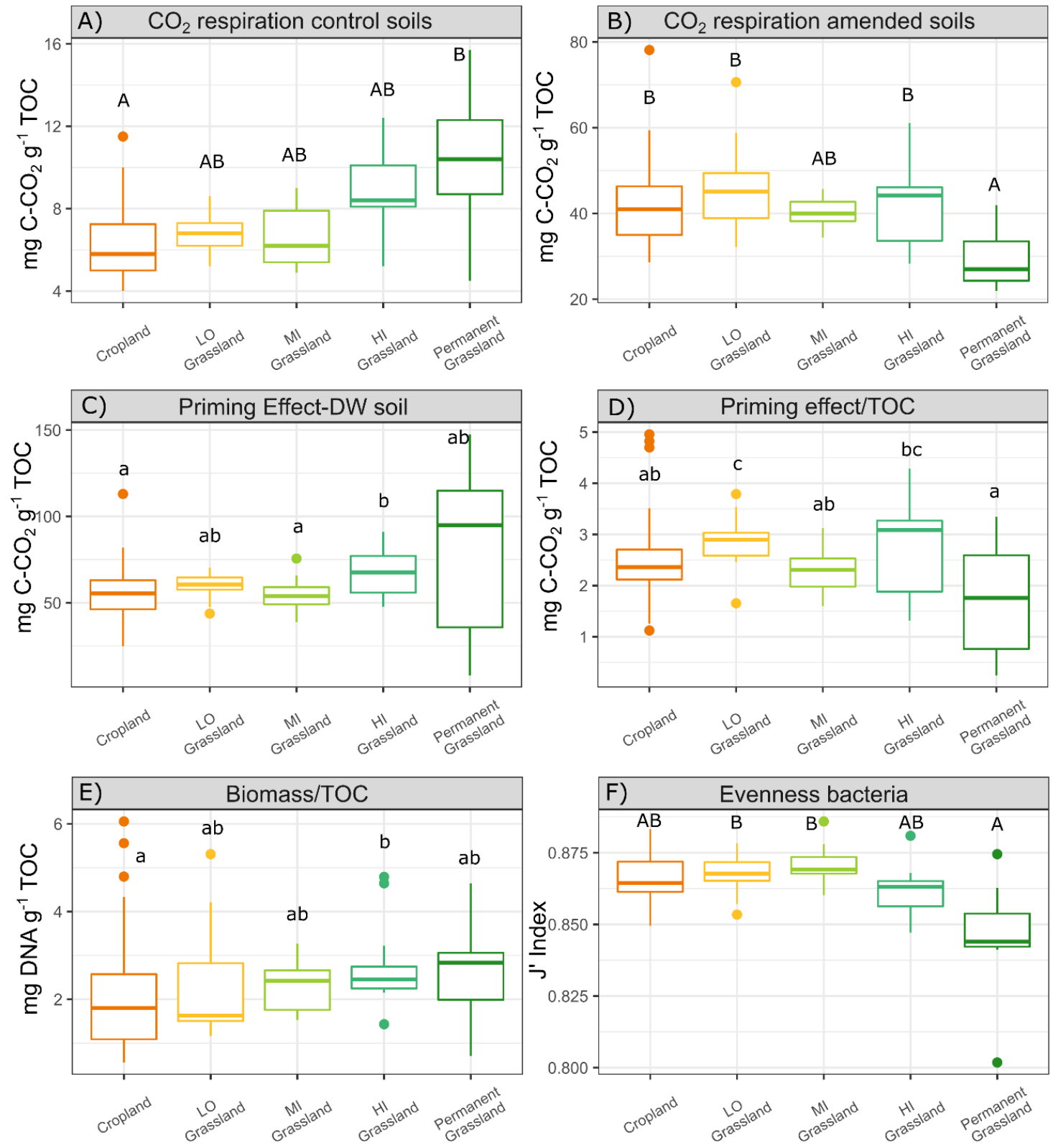
Figure 5

Click here to download Figure: Figure 5.pdf

Figure 5

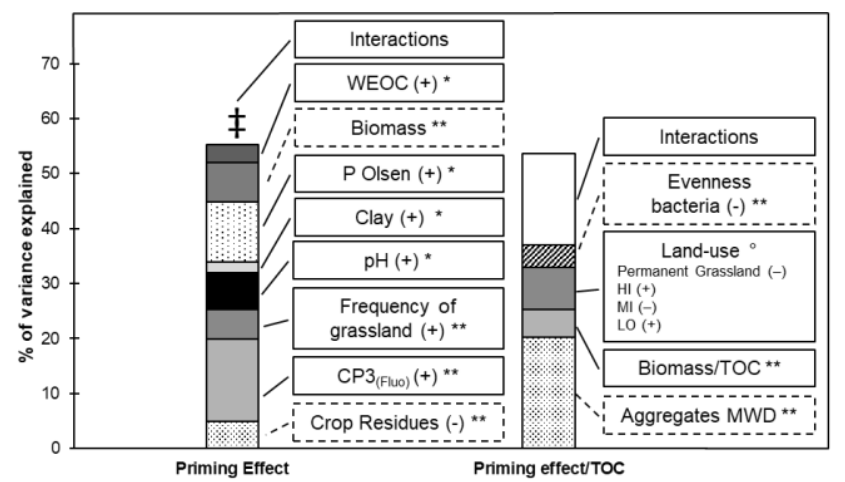

\begin{tabular}{|c|c|c|c|c|}
\hline Predictors & df & Variance explained (\%) & Sign. & Relation \\
\hline \multicolumn{5}{|l|}{ PE/DW soil } \\
\hline Crop Residues & 1 & 4.93 & $\cdots$ & $(-)$ \\
\hline CP3 & 1 & 1506 & .* & $(+)$ \\
\hline Freg grassland & 1 & 5.24 & .* & $(+)$ \\
\hline Soil pH & 1 & 671 & * & $(+)$ \\
\hline Clay & 1 & 203 & . & $(+)$ \\
\hline 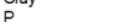 & 1 & 1083 & * & $(+)$ \\
\hline Biomass & 1 & 7.31 & .* & $(-)$ \\
\hline $\begin{array}{l}\text { WEOC } \\
\text { WEOAS }\end{array}$ & 1 & 3.22 & . & $(+)$ \\
\hline interactions & & -6.33 & & \\
\hline $\begin{array}{l}\text { Residuals } \\
\text { PEITCC }\end{array}$ & 79 & 50.98 & & \\
\hline $\begin{array}{l}\text { PE/TOC } \\
\text { MWD }\end{array}$ & 1 & & ** & \\
\hline Biomass/TOC & $\begin{array}{l}1 \\
1\end{array}$ & $\begin{array}{r}20.27 \\
4.98\end{array}$ & .* & $\begin{array}{c}(-) \\
(+) \\
\text { Grassland (-) }\end{array}$ \\
\hline Land-uses & 4 & 7.71 & 。 & $\begin{array}{l}\mathrm{HI}(+) \\
\mathrm{MI}(-) \\
\mathrm{LO}(+)\end{array}$ \\
\hline Evenness_b & 1 & 4.13 & ** & $(-)$ \\
\hline Residual & 80 & 46.38 & & \\
\hline
\end{tabular}

